\title{
Archaeometric researches on the provenance of Mediterranean Archaic Phoenician and Punic pottery
}

\author{
M. L. Amadori ${ }^{1}$ - C. Del Vais ${ }^{2}$ - P. Fermo $^{3} \cdot$ P. Pallante $^{4}$
}

Received: 27 December 2015 / Accepted: 9 June 2016

(C) Springer-Verlag Berlin Heidelberg 2016

\begin{abstract}
The aim of this study is to setup a first chemical database that could represent the starting point for a reliable classification method to discriminate between Archaic Phoenician and Punic pottery on the base of their chemical data. This database up to now can discriminate between several different areas of production and provenance and can be applied also to unknown ceramic samples of comparable age and production areas. More than 100 ceramic fragments were involved in this research, coming from various archaeological sites having a crucial importance in the context of the Phoenician and Punic settlement in central and western Mediterranean: Carthage (Tunisia), Toscanos (South Andalusia, Spain), Sulci, Monte Sirai, Othoca, Tharros (Sardinia, Italy) and Pithecusa (Campania, Italy). Since long-time archaeologists hypothesised that Mediterranean Archaic Phoenician and Punic pottery had mainly a local or just a regional diffusion, with the exception of some particular class like transport amphorae. To verify the
\end{abstract}

Highlights - Archaic Phoenician and Punic pottery from central and western Mediterranean settlements were studied. The statistical treatment of the data (PCA and HCA) has confirmed the reliability of this new and useful database, attesting the presence of importation ceramics (PCA) and allowing a better discrimination between Carthage and local pottery by using two different cluster analyses.

Responsible editor: Philippe Garrigues

M. L. Amadori

maria.amadori@uniurb.it

1 Department of Pure and Applied Sciences, University of Urbino, Urbino, Italy

2 Department of History, Cultural Heritage and Territory, University of Cagliari, Cagliari, Italy

3 Department of Chemistry, University of Milan, Milan, Italy

4 Forgeo, Associated Technical Studio, Modena, Italy pottery provenance, statistical analyses were carried out to define the existence of different ceramic compositional groups characterised by a local origin or imported from other sites. The existing literature data are now supplemented by new archaeometric investigations both on Archaic Phoenician ceramics and clayey raw materials from Sardinia. Therefore, diffractometric analyses, optical microscopy observations and $\mathrm{X}$-ray fluorescence analyses were performed to identify the mineralogical and chemical composition of Othoca ceramics and clayey raw material. The obtained results were then compared with own literature data concerning Phoenician and Punic pottery in order to find features related to the different ceramic productions and their provenance. Principal component analysis (PCA) and hierarchical cluster analysis (HCA) were also performed on the chemical compositional data in order to discriminate ceramic groups. A very complex situation was found: imported ceramics coming from Carthage, with a large-scale distribution, were found together with a predominant local production pottery. The archaeometric results demonstrate that historical and typological approach has to be supported by scientific analyses to better understand local or Mediterranean exchanges.

Keywords Archaic Phoenician and Punic pottery . Archaeometry $\cdot$ optical microscope $\cdot$ XRF analyses $\cdot$ PCA . HCA

\section{Introduction}

Since at least the end of the ninth century BC, the Phoenicians settled on the coast of Lebanon, and in particular those based in Tyre, expanded to the west establishing numerous colonies (Aubet 2009).

The primary area of irradiation is Atlantic Spain, an important metalliferous region, particularly silver-rich. First, they founded 
Cadiz; subsequently, an early colonization of the Mediterranean coast of the Iberian Peninsula occurred, and a series of small settlements located at a short distance from each other, among which was Toscanos, was created with the aim to exploit land and sea resources. Phoenicians founded other colonies also in different areas, in particular in North Africa, in western Sicily and in southwestern Sardinia. In North Africa, the most important colony is certainly Carthage, the direct emanation of the Phoenician city of Tyre, founded probably in the late ninth century BC on the Tunisian coast. In Sicily, between the eighth and seventh century BC, the colonies of Mothya, Panormos and Solunto were founded. In Sardinia, several coastal settlements, implanted between the Gulf of Cagliari and the Gulf of Oristano, were colonised. In the region of Sulcis, which is rich in mineral deposits, in the eighth century BC the city of Sulci (Sant'Antioco) was built; later secondary centres including Monte Sirai (Carbonia) were settled. The main Phoenician centres in the Gulf of Oristano are Othoca (Santa Giusta) and Tharros (Cabras); it is not yet clear if their foundation should be related to the eighth or seventh century BC. Pithecusa, the oldest Greek colony in the west, is located in Ischia island to a short distance from the coast of Campania. It is an important area useful in reconstructing archaic trades between Greeks and Phoenicians because many oriental imported materials are found in the necropolis and in the acropolis.

The first centuries of the west Phoenician irradiation (Fig. 1) are very complex: different components of eastern origin interact fairly quickly with the local components of the areas affected by colonization.

Among all the Phoenician colonies of the west, Carthage developed very early trade activities and cultural influences mainly in the central Mediterranean; in the second half of the sixth century BC, the colony had political control of the western Sicily and southwest Sardinia too.

The common archaeological approach in the research concerning the Phoenician and Punic pottery, which was predominant till recent times, determined the conviction that coarse and fine pottery had a local diffusion or just a regional one, with the exception of the same particular classes like transport amphorae.

To overcome this approach and to have a more comprehensive overview of the phenomena governing the Phoenician centres of ceramic production in the west, an archaeometric research project was carried out on more than 100 potsherds coming from several centres located in the West Central Mediterranean area in order to achieve a complete characterisation of the ceramic bodies. This research, which was started in 1987, dealt with Archaic Phoenician and Punic ceramics found in different excavation sites: Carthage (Tunisia), Toscanos (Spain), Sulci (Sant'Antioco-Italy), Monte Sirai (Carbonia-Italy), Tharros (Cabras-Italy) and Pithecusa (Ischia-Italy) (Amadori et al. 1996; Amadori and Fabbri 1998a, b, c; Peserico 1998, 2000). The research is now supplemented by the analysis of coeval ceramics and clayey raw materials from Othoca (Santa Giusta-OR).

\section{Materials}

More than one hundred potsherds were selected (Table 1) between different functional and productive ceramic categories. The finds were dated from the eighth to sixth/beginning

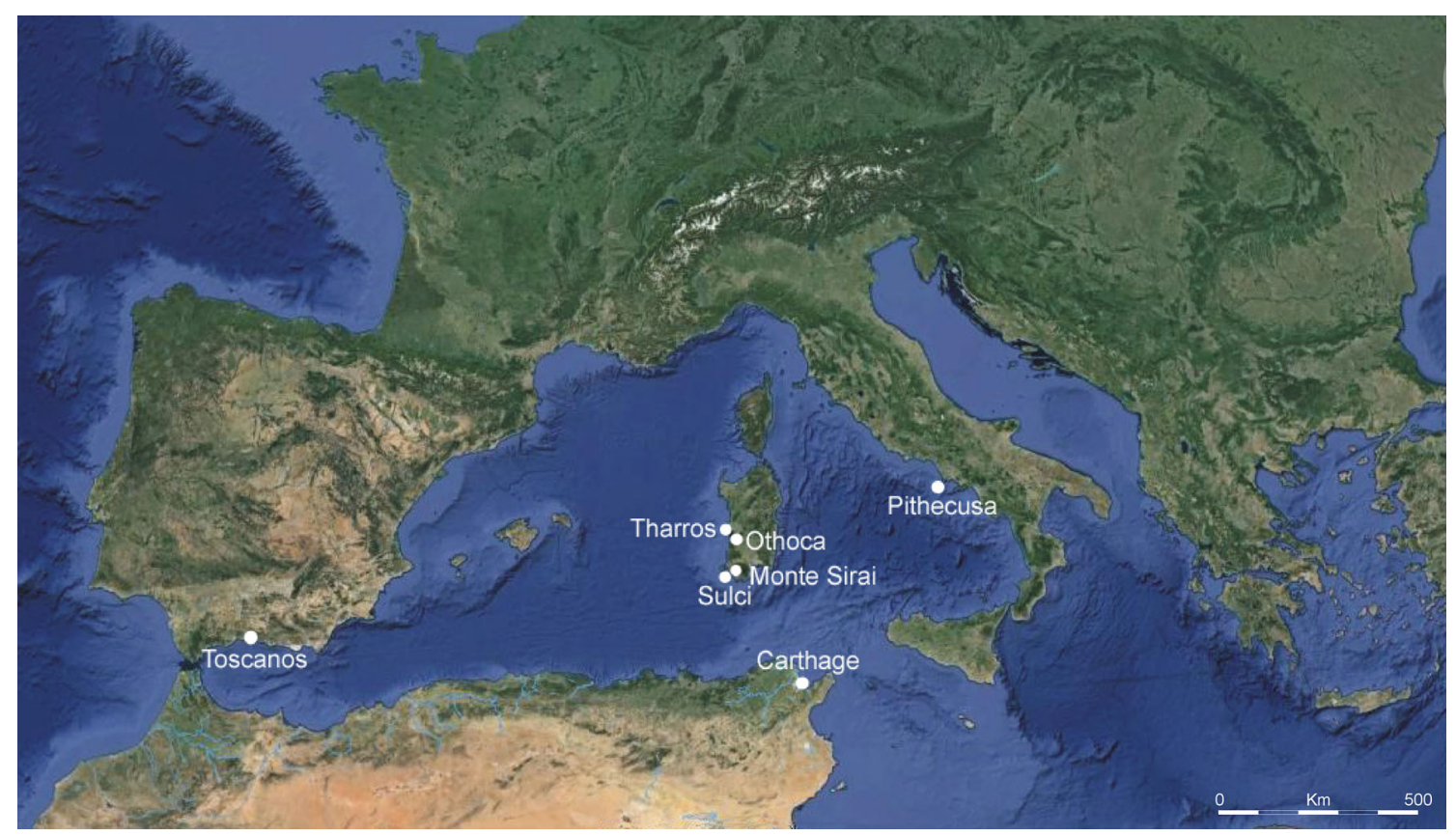

Fig. 1 Map of the settlements mentioned in the article 
Table 1 List and description of ceramic samples

\begin{tabular}{|c|c|c|c|}
\hline Location & Sample & Form & Dating century BC \\
\hline \multirow[t]{32}{*}{ CARTHAGE } & CA 435 & Plate P1 & $750-650$ \\
\hline & CA 1183 & Plate P1 & $750-650$ \\
\hline & CA 1216 & Plate P1 & $750-650$ \\
\hline & CA 1439 & Plate P1 & $750-650$ \\
\hline & CA 1447 & Plate P1 & $750-650$ \\
\hline & CA 1456 & Plate P1 & $750-650$ \\
\hline & CA 1622 & Plate P1 & $750-650$ \\
\hline & CA 295 & Carinate cup CCr5 & $750-650$ \\
\hline & CA 615 & Carinate cup CCr5 & $750-650$ \\
\hline & CA 1075 & Carinate cup $\mathrm{CCr} 5$ & $750-650$ \\
\hline & CA 297 & Flat base B1 & $750-650$ \\
\hline & CA 888 & Lamp L2 & End of the eighth-end of the sixth \\
\hline & CA 605 & Carinate cup CCr3 & Beginning of the seventh-575 \\
\hline & CA 34 & Carinate cup CCc1 & Beginning of the seventh-550 \\
\hline & CA 35 & Carinate cup CCc1 & Beginning of the seventh-550 \\
\hline & CA 152 & Carinate cup CCc1 & Beginning of the seventh-550 \\
\hline & CA 217 & Carinate cup CCc1 & Beginning of the seventh-550 \\
\hline & CA 221 & Carinate cup CCc1 & Beginning of the seventh-550 \\
\hline & CA 1685 & Skyphos S & Beginning of the seventh-beginning of the sixth \\
\hline & CA 1184 & Plate P2 & $650-500 / 475$ \\
\hline & CA 1576 & Plate P2 & $650-500 / 475$ \\
\hline & CA 1126 & Plate P3 & $650-500 / 475$ \\
\hline & CA 1204 & Plate P3 & $650-500 / 475$ \\
\hline & CA 64 & Carinate cup CCr1 & $650-500 / 475$ \\
\hline & CA 194 & Carinate cup CCr1 & $650-500 / 475$ \\
\hline & CA 3 & Carinate cup CCr4 & $650-500 / 475$ \\
\hline & CA 757 & Not carinate cup $\mathrm{CsC} 5$ & $650-500 / 475$ \\
\hline & CA 1049 & Not carinate cup $\mathrm{CsC} 5$ & $650-500 / 475$ \\
\hline & CA 124 & Bowl Bic & $650-500 / 475$ \\
\hline & CA 1013 & Plate & Ind. \\
\hline & CA 1573 & Plate & Ind. \\
\hline & CA 1590 & Plate & Ind. \\
\hline \multirow[t]{17}{*}{ TOSCANOS } & TO 862 & Plate & $700-685$ \\
\hline & TO 570 & Plate & $640-620$ \\
\hline & TO 674 & Plate & 620-ind. \\
\hline & TO 689 & Plate & 620-ind. \\
\hline & TO 702 & Plate & 620-ind. \\
\hline & TO 63 & Base & $710-700$ \\
\hline & TO 667 & Base & $685-620$ \\
\hline & TO 727 & Base & 620-ind. \\
\hline & TO 13 & Cup & $710-700$ \\
\hline & TO 86 & Cup & $685-660$ \\
\hline & TO 87 & Cup & $685-660$ \\
\hline & TO 108 & Cup & $685-660$ \\
\hline & TO 478 & Skyphos & $685-660$ \\
\hline & TO 391 & Plate & $685-660$ \\
\hline & TO 584 & Plate & $640-620$ \\
\hline & TO 180 & Base & $685-660$ \\
\hline & TO 212 & Base & $685-660$ \\
\hline
\end{tabular}


Table 1 (continued)

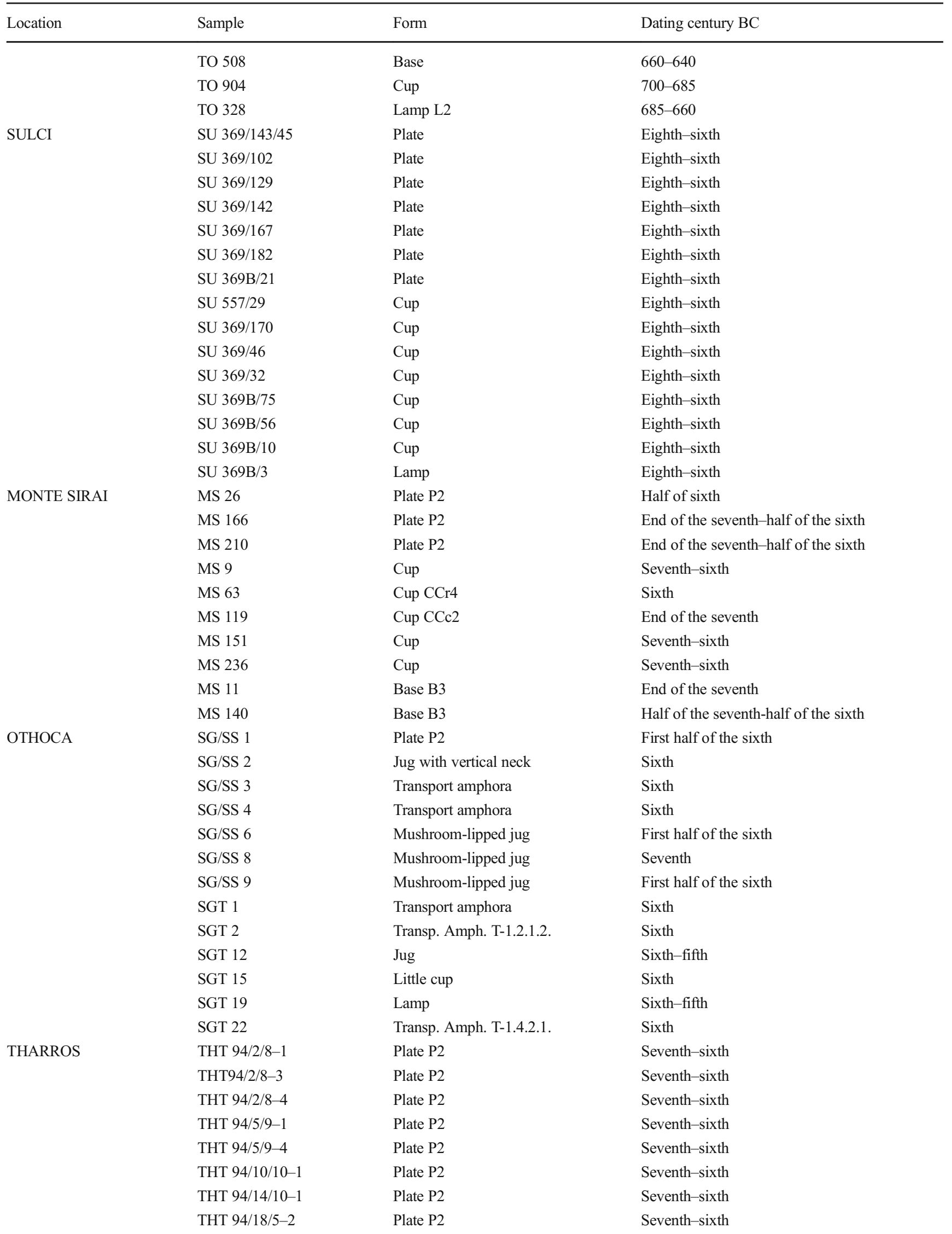


Table 1 (continued)

\begin{tabular}{llll}
\hline Location & Sample & Form & Dating century BC \\
\hline & THT 94/18/8-2 & Plate P2 & Seventh-sixth \\
THT 94/18/8-3 & Plate P2 & Seventh-sixth \\
THT 94/22/6-1 & Plate P2 & Seventh-sixth \\
THT 94/47/5-1 & Plate P2 & Seventh-sixth \\
PITHECUSA & PI 2 & Plate P1 & Half of the eighth-half of the seventh \\
& PI 12 & Plate P1 & Half of the eighth-half of the seventh \\
PI 14 & Base B3 & Half of the eighth-half of the seventh \\
PI 10 & Lamp L2 & Half of the eighth-half of the seventh \\
\hline
\end{tabular}

of the fifth century BC and came from different Phoenician and Punic excavation sites. Various samples were analysed, partly belonging to tableware forms such as plates, cups, bowls and skyphoi, partly belonging to other functional categories, such as lamps, funerary jugs and transport amphorae. The unusual choice to study also open forms is determined by the intention of considering specific cultural aspects of the Phoenician and Punic society and its eating habits regarding other forms that are most commonly linked to local production; the transport amphorae in fact have higher commercial and economic implications affecting the production and transportation of foodstuff along commercial circuits of medium and large scale.

In this work, we have followed the classification proposed by Peserico for open shapes (Peserico 1998, 2000, 2002) and the one proposed by J. Ramon Torres for transport amphorae (Ramon Torres 1995). We use the definition of "Phoenician pottery" for materials produced in archaic contexts most linked to the oriental motherland, and we use the definition of "Punic pottery" for materials of Carthaginian production or Carthaginian morphological type.

Carthage samples (CA samples): plates (types P1, P2, P3), cups (types $\mathrm{CCr} 1, \mathrm{CCr} 3, \mathrm{CCr} 4, \mathrm{CCr} 5, \mathrm{CCc} 1$, CsC5), a bowl (type Bic), an imitation skyphos (type S), a lamp (type L2) and a base (type B1) were selected (32 samples). The samples come from the excavation conducted by the University of Hamburg in an Archaic residential area under the Cardo Maximus, directed by H.G. Niemeyer (Peserico 1998, 2000, 2002; Niemeyer et al. 2007), and they are dated between 750 and the beginning of the fifth century BC. The city, founded by the Phoenicians of Tyre in the late ninth century BC, since archaic phases assumes a leading role in the central Mediterranean that becomes dominant since the sixth century BC. The presence of Carthaginian pottery in other Mediterranean areas in the eighth to seventh centuries
$\mathrm{BC}$ can show the existence of commercial contacts linked to cultural influences exerted by the city since archaic periods.

Toscanos samples (TO samples): plates, cups, bases, a lamp and an imitation skyphos were investigated (twenty samples) (Amadori and Fabbri 1998c; Peserico 2000, 2002). All of them are dated between the half of the eighth century to the sixth century BC. The samples come from the area of the warehouse, excavated by the German Institute of Archaeology in Madrid (dir. H. Schubart). This settlement is part of the colonial programme conducted by the Phoenicians along the Mediterranean coasts of Andalusia aimed at the capillary use of land and sea and to establish business relationships with the indigenous hinterland. Toscanos belongs to a political and cultural context more related to west Spain and the commercial circle created by the Phoenicians in the Strait of Gibraltar; nevertheless, the presence of the westcentral imported pottery indicates the existence of contacts with that area.

Sulci samples (SU samples): plates, cups and a base were investigated (fifteen samples) (Amadori and Fabbri 1998b; Peserico 2000, 2002). All of them are dated between the half of the eighth to the sixth century BC. The samples come from the residential area of the "Cronicario", excavated by the Archaeological Superintendence of Cagliari and Oristano (dir. P. Bernardini). In this area, the oldest Phoenician residential traces in Sardinia, which document the foundation of an archaic colony, were found and probably related to the exploitation of massive metal resources of the Sulcis region.

Monte Sirai samples (MS samples): plates (P2), cups $(\mathrm{CCr} 4, \mathrm{CCc} 2)$ and bases (B3) were investigated (ten samples) (Peserico 1994; Amadori and Fabbri 1998b; Peserico 2000). All of them are dated between the seventh and sixth century $\mathrm{BC}$. The samples come from a residential area of the "acropolis", excavated by the Institute for Phoenician and Punic civilization (CNR- 
Rome) and by the Archaeological Superintendence of Cagliari and Oristano (dir. P. Bartoloni). The settlement of Monte Sirai is generally considered a secondary colony of Sulci; it was founded to control the immediate hinterland. Perhaps the cultural and economic level was not very high but closely related to the coastal city.

Othoca samples (SG/SS and SGT samples): the SG/SS samples come from cremation graves of the necropolis of Othoca (Santa Severa locality), dating from the seventh century to the half of sixth century BC, excavated by the Archaeological Superintendence of Cagliari and Oristano and the University of Cagliari (Del Vais 2010); jugs (three mushroom-lipped jug; an ovoid jug with vertical, stepped neck), two transport amphorae (ind. type) and a plate (type P2) were investigated (seven samples). The SGT samples come from an underwater deposit of the Phoenician and Punic periods identified in the Lagoon of Santa Giusta, the basin connected to the port of the ancient city, excavated by the Archaeological Superintendence of Cagliari and Oristano in collaboration with the University of Cagliari (Del Vais and Sanna 2012); four transport amphorae (T-1.2.1.2. and $\mathrm{T}-1.4 .2 .1$.), a domestic jug and a little cup were investigated, all dating from the late seventh century to the beginning of the fifth century BC (six samples). The city of Othoca was founded by the Phoenicians to control the central sector of the Gulf of Oristano, probably in relation to the exploitation of the rich resources of the agricultural and mountainous hinterland. We have chosen to analyse both open and closed forms and transport amphorae because new researches gave us the opportunity to compare a funerary context, therefore linked to the local ritual practises, with a commercial one. In particular, the existence of possible cultural and economic relations with other regions was tested and a production of transport amphorae related to the foodstuff processing was hypothesised, thanks to the presence of palaeobotanic and animal remains in these transport amphorae.

Tharros samples (THT samples): red slip plates produced between half of the seventh and sixth century BC were studied (twelve samples) (Amadori and Fabbri 1998b; Peserico 2000). The samples come from the pyrometallurgical district of the hill of "Su Murru Mannu", excavated by the Institute for Phoenician and Punic civilization (CNR - Rome), the Archaeological Superintendence of Cagliari and Oristano and the University of Bologna, directed by E. Acquaro. The city of Tharros, situated in the northern sector of the Gulf of Oristano, still represents one of the Sardinian colonies showing the major cultural influences from Carthage since the Archaic period.

Pithecusa samples (PI samples): two plates (type P1), a base (type B3) and a lamp (type L2) were investigated (four samples) (Amadori and Fabbri 1998b; Peserico
2000, 2002). All of them are dated between half of the eighth and half of the seventh century BC. The samples come from the San Montano necropolis and from the "scarico Gosetti" of the Monte Vico acropolis (Docter 2000; Peserico 2000), excavated by the Archaeological Superintendence of Naples and Caserta (dir. G. Buchner and D. Ridgway). Pithecusa is the oldest Greek colony in the west founded by the Euboean but frequented by Levantines and open to the influence of Carthage; from this point of view, it is a privileged observatory to understand the interrelation of cultural phenomena linked to the most ancient oriental occupation phases in central Mediterranean.

Raw materials: in addition to the described pottery, seven clays from the Tharros area and seven clays from the Othoca area have been considered (Table 2) to identify the source materials of the local pottery production.

Tharros clays were collected from different ages clay formations, outcropping in the surroundings of Tharros settlement (Fig. 2 a): four samples of Miocene clays (two of Tortonian and two of Messinian formations), one from Pliocene and two from Quaternary clay formations (Amadori et al. 1996).

Othoca clays (Fig. 2 a-b) were collected from Santa Giusta Lagoon (one sample), from Othoca necropolis near Santa Severa church (one sample) and close to Othoca site (five samples) which are related to different Holocenic (Quaternary) clay formations located in the area of Santa Giusta, the modern village that has developed over the ancient city of Othoca.

\section{Methods}

The following analytical methodologies were applied:

(a) Determination of the chemical composition (i.e. $\mathrm{Si}, \mathrm{Al}$, $\mathrm{Ca}, \mathrm{Ti}, \mathrm{Mg}, \mathrm{Fe}, \mathrm{Mn}, \mathrm{K}, \mathrm{Na}, \mathrm{P}$ ) by X-ray fluorescence (XRF) on pellets. Both own and literature samples were analysed with the same analytical technique (WD-XRF) but with a different equipment (Philips PW 1480 in Modena University with Sc-Mo anode and Philips PW 1480 with a W anode in Faenza). Major and minor elements were analysed by WD-XRF, and no trace elements were detected as they were not analysed in the previous investigations. XRF analyses were performed to identify the chemical composition of Othoca ceramics and clayey raw materials. The obtained results were then compared with literature data concerning Phoenician-Punic pottery (Carthage: Amadori and Fabbri 1998a; Peserico 1998, 2000, 2002; Toscanos: Amadori and Fabbri 1998c; 
Table 2 List and description of clay samples

\begin{tabular}{lll}
\hline Sample & Clay formation age & Location (Figs 2 a-b) \\
\hline T1 & Tortonian & San Marco Cape, Tharros \\
T2 & Messinian & San Marco Cape-San Giovanni tower, Tharros \\
M2 & & \\
M6 & Pliocene & North of Tharros \\
Nu1 & Quaternary & San Marco Cape, Tharros \\
M12 & & West of Nuraghe Baboe Cabitza, San Marco Cape \\
ZA & Holocene & Santa Giusta Lagoon \\
SGT ARG & & Othoca necropolis \\
US 46 & & Santa Giusta village \\
AREA 1 & & \\
AREA 2 & & \\
AREA 3 & & \\
AREA 4 & & \\
AREA 5 & & \\
\hline
\end{tabular}

a

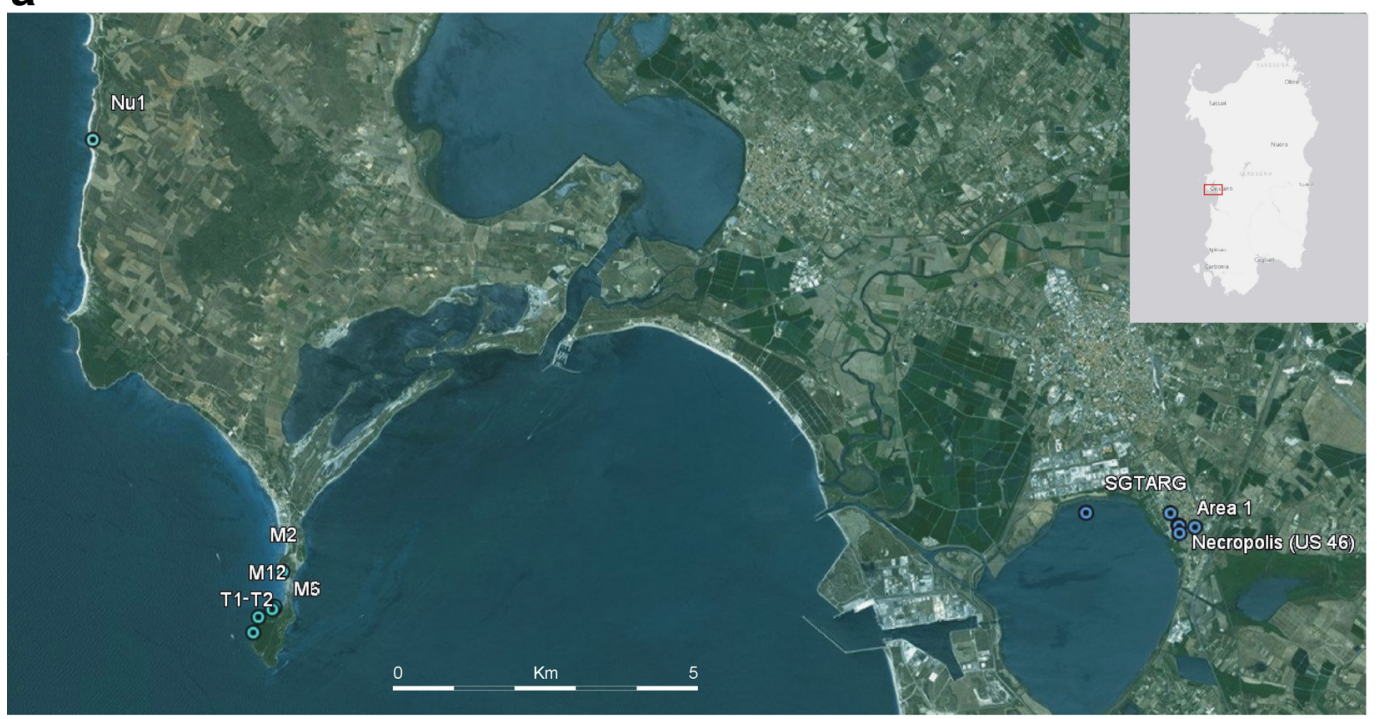

b

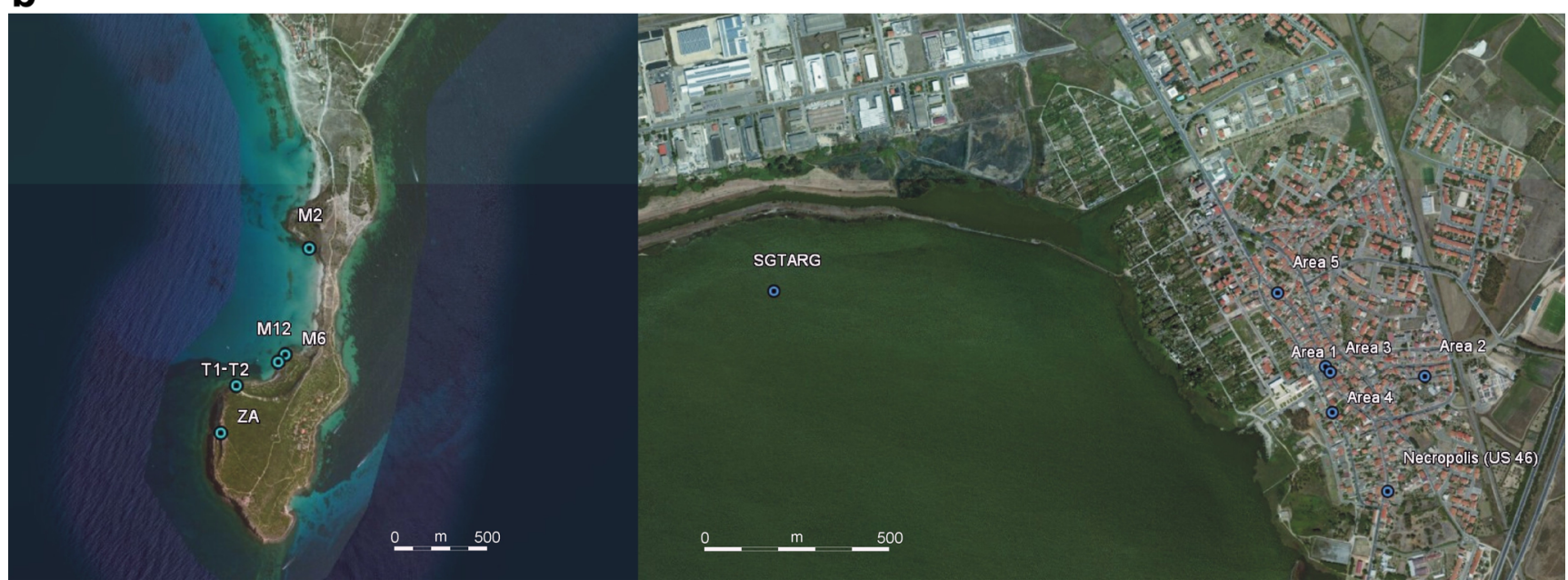

Fig. 2 a Clay sample provenance, b Clay sample provenance 
Sulci, Monte Sirai, Tharros and Pithecusa: Amadori and Fabbri 1998b) and clayey raw materials (Amadori et al. 1996) to find features related to the different ceramic productions and their provenance. To compare own previous data with Othoca new results, all chemical data were processed and recalculated by considering also the Loss on Ignition (LOI) and the P in the global composition of the samples (Table 2). LOI and P were often reported in literature data but were never considered in the data treatment and in the global composition of the samples. The re-considering of these parameters and the re-calculation of the chemical composition (100\% total) was necessary for an effective comparison between all the data following the same approach.

(b) XRF data were treated by means of chemometric analytical techniques, such as principal component analysis (PCA) and hierarchical cluster analysis (HCA). In particular, PCA and HCA were applied considering as variables the elements (oxides) determined by XRF. All the graphs reported in the text (scatter plots and two dendrogram) were realised by using the statistical packages Minitab Inc. 15.1 and STATISTICA 7.1. PCA was carried out on the data covariance matrix.

Both of them are well-known multivariate methods of analysis (Baxter 1994; Baxter and Buck 2000). PCA involves a mathematical procedure that transforms a number of possibly correlated variables into a smaller number of uncorrelated variables called principal components. HCA refers to a group of techniques of multivariate analysis whose objective is to select and group together homogeneous data. All these techniques are based on the concept of distance between two elements. The algorithm used for the analysis groups together the elements on the base of their reciprocal distance and therefore one element belongs to a group depending on the distance from that group. In the literature, these two techniques have been successfully applied in archaeological applications to solve provenance problems (Fermo et al. 2004, 2008; Padeletti and Fermo 2010).

(c) Polarization microscopy was carried out on the thin sections of ceramic slices $(25 \mu \mathrm{m})$ with a BX51 Olympus instrument polarised light. Mineralogical characterisation as well as surface modification was interpreted by means of the AnalySIS five pictures Software (Olympus Corporation, USA). The minerals were identified by means of their typical birefringence, also with supplementary petrographical interpretation using the multiple image alignment (MIA) technique. Dark and bright field observations were performed with fixed oculars of $\times 10$ and objectives with different magnifications $(5,10,20,50$ and $\times 100$ ) on thin polished sections. (d) Crystalline phase composition was determined by X-ray diffraction (XRD) on powder samples using a Philips PW 1830 diffractometer continuous scanning filter with nickel. The following conditions were applied: emission radiation $\mathrm{Cu}, \mathrm{Ka}$, voltage $40 \mathrm{kV}$, intensity $40 \mathrm{~mA}$, goniometer speed $0.12 \mathrm{~h} / \mathrm{s}$.

\section{Results}

\section{Carthage samples}

The mineralogical and petrographic investigations on Carthage samples allowed identification of the presence of ceramic bodies with a limited variability in the general matrix features (isotropy, colour, porosity, etc.), in the total abundance of the skeleton (approximately 10-20\%) and in lithological or mineralogical composition of the aplastic fractions. The latter are almost always represented by monocrystalline and polycrystalline quartz, carbonate rocks fragments, bioclasts, chert, feldspars, opaque minerals, hematite and rare biotite.

The only clear and discriminating variable among the paste is the different size class distribution of aplastics. This aspect has allowed the identification of two major groups of samples (Figs. 3a, b), each subdivided into two sub-groups, and some samples (isolated samples) scattered because they were hardly comparable to others in terms of grain size. The first group, $\mathrm{C} 1$, has a serial grain size distribution of aplastic with an abundance of silty and very fine sandy fraction. In the second group, C2, aplastics have a hiatal grain size distribution with fine and very fine sandy fraction.

The XRD analysis showed that ceramic samples are composed of quartz, calcite and K-feldspars; sometimes plagioclase and haematite are present too (Table 3). The samples are practically free from formation of minerals (gehlenite and pyroxene) and as a consequence, it can be deduced that the maximum temperature reached was around $750{ }^{\circ} \mathrm{C}$. Traces of gehlenite were founded only in five samples indicating a higher firing temperature, estimated at around $800{ }^{\circ} \mathrm{C}$. In fact, in accordance with Cultrone et al. (Cultrone et al. 2001), gehlenite appears at $800{ }^{\circ} \mathrm{C}$ increasing at $900{ }^{\circ} \mathrm{C}$ (Cultrone et al. 2001; Padeletti and Fermo 2010). Gehlenite can occur in two varieties: the first via a decarbonization process and recrystallization by means of increasing $\mathrm{CaO}$ amount in high temperature reaction (Emami and Trettin 2010) or second, by using coarse grain calcareous materials via a firing process (Heimann and Maggetti 1981). The grain size of the raw mix is a considerable factor for the exhibition of high temperature phases (Noll 1991). According to this case, gehlenite was not formed in a well-grained material, and therefore gehlenites have a sharp peak above the background in the diffractograms. 
Fig. 3 a Sample CA 35, transmitted light micrograph, XPL, $\mathrm{C} 1$ group. Carinate cup, Carthage (local); b sample CA 1456, transmitted light micrograph, XPL, C2 group. Carinate cup, Carthage (local)
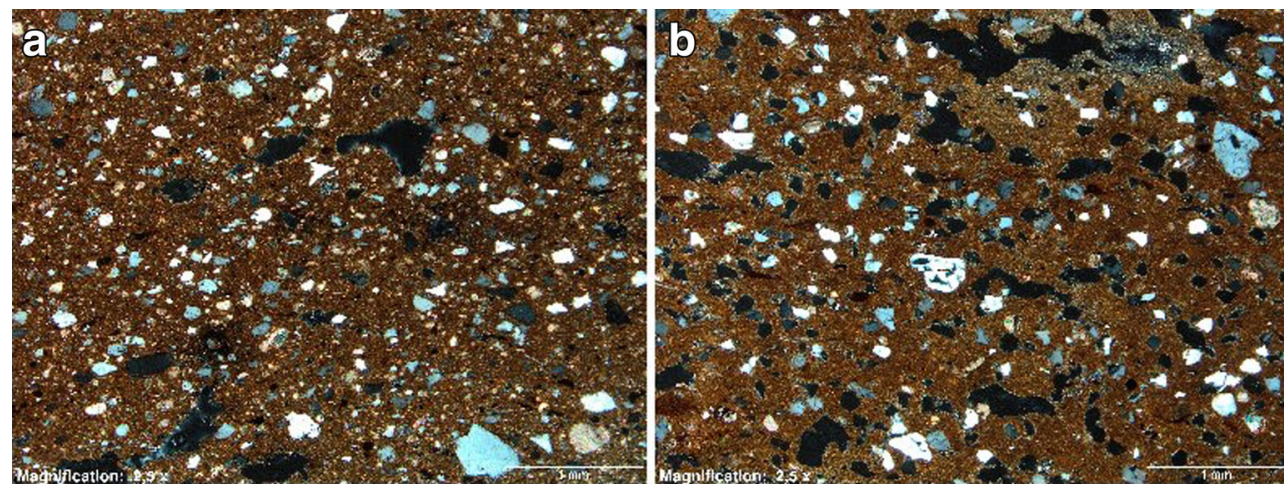

The chemical composition of Carthage ceramics, obtained by XRF analyses, shows a high homogeneity for most of the elements considered (Table 4). The samples are characterized by a quite high $\mathrm{CaO}$ content (average value of $17.2 \%$ and standard deviation of $3.16 \%$ ), medium to low alumina concentrations (average value of $11.3 \%$ and standard deviation of $1.1 \%$ ) and extremely constant and not particularly high iron content (average value of $4.9 \%$ and standard deviation of $0.33 \%$ ). The average values of other chromophores, like manganese and titanium oxides, ranges from 0.03 to $0.65 \%$, respectively. The widest variations are evidenced for $\mathrm{CaO}, \mathrm{SiO}_{2}$ and LOI.

By considering binary correlation diagrams, the samples are related to two groups also from the chemical point of view, namely, $\mathrm{C} 1$ and $\mathrm{C} 2$. These two groupings are present in several binary correlations (i.e. $\mathrm{MgO}-\mathrm{CaO}$; Fig. 4) and suggest a primary differentiation that can be due to different areal productions within Punic pottery entailing different prime matters used or to a non-coeval production. As for the five isolated samples, the chemical affinity with the $\mathrm{C} 1$ and $\mathrm{C} 2$ groups seems quite evident in the correlation diagram of Fig. 4.

In the correlation diagram between the $\mathrm{CaO}$ and $\mathrm{LOI}$ (Fig. 5), some parallel trends are present. A first one (upper line in Fig. 5), which is an almost constant correlation, is mainly due to the presence of variable amounts of calcite inside the pastes. A lower trend (samples CA 221, CA 152, CA 1013, CA 1622, CA 1204, CA 217, CA 3) with a CaOLOI constant ratio, but with a lower LOI content, is present. In the lowest trend (samples CA 435, CA 1685, CA 605, CA 295), this behaviour is even more evident, and once again, both samples from the $\mathrm{C} 1$ and $\mathrm{C} 2$ groups are present. Finally, two samples belonging to the $\mathrm{C} 2$ group (CA 888, CA 1184) and an isolated sample (CA 1590) with a quite relevant $\mathrm{CaO}$ content (14.4-21.4\%) have the lowest LOI.

The existence of these several and almost parallel trends can not only be due to different $\mathrm{CaO}$ contents in the pastes (clays and/or fillers) but also to higher plagioclase contents or to the presence of neoformation minerals (like gehlenite), as suggested by the XRD analyses (Table 3 ).
The typological study carried out on the Carthage samples attests that the two local manufactures can be ascribed to different manufactures: an ancient one (production $\mathrm{C} 1$ ), active between 750 to $650 \mathrm{BC}$, has a morphologic repertory constituted by original shapes or derived from oriental prototypes (plate P1; cup CCr5; base B1). A second one (production C2), dated from 650 to the end of the sixth/beginning of the fifth century $\mathrm{BC}$, is represented by occidental shapes or evolved ones from oriental tradition (plates P2, P3; bowl Bic; cups $\mathrm{CsC} 5, \mathrm{CCr} 1, \mathrm{CCr} 4)$. Other shapes (cups CCc1, CCr3; skyphos S; lamp L2), dated from the beginning of the seventh to the half of the sixth century $\mathrm{BC}$, were produced by both productions (Amadori and Fabbri 1998a; Peserico 1998, 2000, 2002).

\section{Toscanos samples}

Concerning the materials from Toscanos, mineralogical and petrographic investigations allowed identification of two main pottery groups (Fig. 6a, b). The T1 group is composed of thirteen samples with an anisotropic matrix and a series of aplastic grain size distribution, with an abundance of silty and very fine sandy fraction, while other fractions are typically scarce or in traces. Skeleton abundance is in almost all the samples of about $10 \%$. The aplastic fraction is made of monocrystalline quartz and more rarely polycrystalline and metamorphic rock fragments. Quartz and mica, quartz, garnet, mica, kyanite, epidote and feldspars, quartz and feldspar, sometimes altered, mica and andalusite, chlorite, kyanite and andalusite are present. Furthermore, few carbonate rock fragments, bioclasts, opaque minerals, hematite, flint and rare sedimentary rock fragments (quartzite and siltstones) are present too. Most of the components of the skeleton is therefore due to micaschiste, greenschist and phyllitic rocks correlated with the geological area of Toscanos.

The second group (T2) is made up of seven samples with anisotropic matrix. They are characterized by a hiatal grain size distribution of aplastic represented by fine sandy fractions. The aplastic abundance is around $10 \%$. The skeleton consists of monocrystalline quartz, carbonate rock fragments, 
Environ Sci Pollux Res

Table 3 Mineralogical compositions of ceramic samples (XRD)

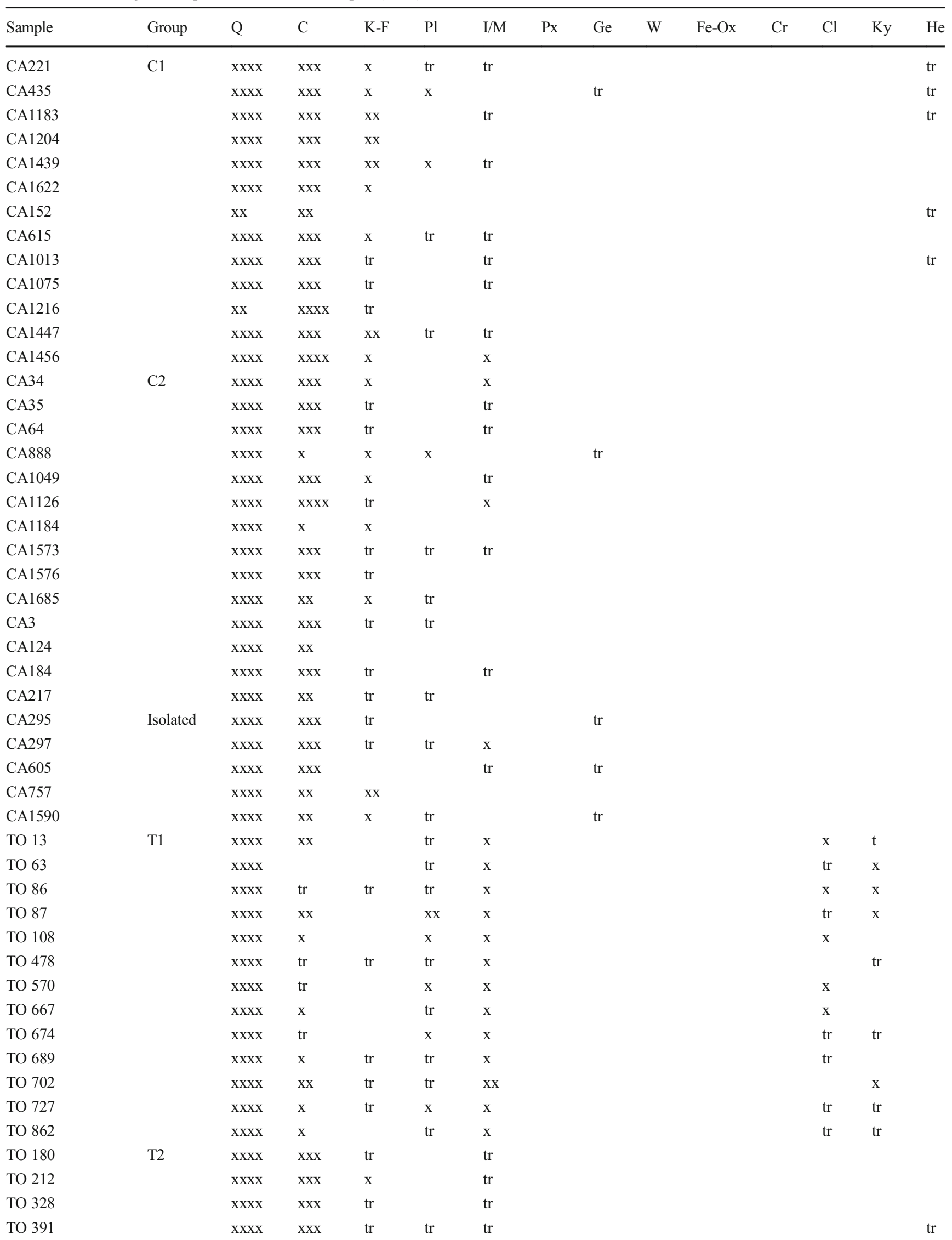

Springer 
Table 3 (continued)

\begin{tabular}{|c|c|c|c|c|c|c|c|c|c|c|c|c|c|c|}
\hline Sample & Group & Q & $\mathrm{C}$ & $\mathrm{K}-\mathrm{F}$ & $\mathrm{Pl}$ & $\mathrm{I} / \mathrm{M}$ & Px & $\mathrm{Ge}$ & W & $\mathrm{Fe}-\mathrm{Ox}$ & $\mathrm{Cr}$ & $\mathrm{Cl}$ & $\mathrm{Ky}$ & $\mathrm{He}$ \\
\hline TO 508 & & $\operatorname{xxxx}$ & $\mathrm{xxx}$ & $\operatorname{tr}$ & $\operatorname{tr}$ & $\operatorname{tr}$ & & & & & & & & \\
\hline TO 584 & & $\operatorname{xxxx}$ & $\operatorname{xxxx}$ & $\operatorname{tr}$ & & $\operatorname{tr}$ & & & & & & & & \\
\hline TO 904 & & $\operatorname{xxxx}$ & $\operatorname{xxxx}$ & $\mathrm{x}$ & & $\operatorname{tr}$ & & & & & & & & \\
\hline SU 369B/10 & $\mathrm{S} 1$ & $\operatorname{xxxx}$ & & $\mathrm{xx}$ & $\mathrm{xx}$ & $\mathrm{x}$ & $\operatorname{tr}$ & & & & $\mathrm{xx}$ & & & $\operatorname{tr}$ \\
\hline SU 369B/56 & & $\operatorname{xxxx}$ & & $\mathrm{xx}$ & $\mathrm{xx}$ & $\mathrm{x}$ & $\operatorname{tr}$ & & & & $\mathrm{x}$ & & & \\
\hline SU 369B75 & & $\operatorname{xxxx}$ & & $\mathrm{xxx}$ & $\mathrm{xx}$ & $\mathrm{x}$ & $\operatorname{tr}$ & & & & $\mathrm{x}$ & & & \\
\hline SU 369/142 & & $\operatorname{xxxx}$ & & $\mathrm{xx}$ & $\mathrm{xx}$ & $\mathrm{x}$ & $\operatorname{tr}$ & & & & $\operatorname{tr}$ & & & \\
\hline SU 369/182 & & $\operatorname{xxxx}$ & & $\mathrm{xxx}$ & $\mathrm{xxx}$ & $\mathrm{x}$ & $\mathrm{x}$ & $\operatorname{tr}$ & & & $\mathrm{xx}$ & & & \\
\hline SU 369/46 & & $\operatorname{xxxx}$ & & $\mathrm{xxx}$ & $\mathrm{xxx}$ & $\mathrm{x}$ & $\mathrm{x}$ & $\operatorname{tr}$ & & & $\mathrm{xx}$ & & & \\
\hline SU 369/167 & & $\operatorname{xxxx}$ & & $\mathrm{xx}$ & $\mathrm{xxx}$ & $\mathrm{x}$ & $\mathrm{x}$ & & & & $\mathrm{x}$ & & & \\
\hline SU 369B/21 & & $\operatorname{xxxx}$ & & $\mathrm{xx}$ & $\mathrm{xx}$ & $\mathrm{x}$ & & & & & $\operatorname{tr}$ & & & \\
\hline SU 369/143/45 & & $\operatorname{xxxx}$ & & $\mathrm{xx}$ & $\mathrm{xx}$ & $\mathrm{x}$ & & & & & $\mathrm{xx}$ & & & \\
\hline SU 369/32 & & $\operatorname{xxxx}$ & & $\mathrm{xxx}$ & $\mathrm{xxx}$ & $\mathrm{x}$ & $\operatorname{tr}$ & $\operatorname{tr}$ & & & & & & \\
\hline SU 369/102 & $\mathrm{S} 2$ & $\mathrm{xxxx}$ & $\mathrm{xxx}$ & $\operatorname{tr}$ & & $\operatorname{tr}$ & $\mathrm{x}$ & $\operatorname{tr}$ & & & & & & $\operatorname{tr}$ \\
\hline SU 369/129 & & $\mathrm{xxxx}$ & $\mathrm{xxx}$ & $\mathrm{x}$ & & $\operatorname{tr}$ & & $\operatorname{tr}$ & & & & & & \\
\hline SU 369/170 & & $\operatorname{xxxx}$ & $\mathrm{xx}$ & $\mathrm{x}$ & & & & & & & & & & $\operatorname{tr}$ \\
\hline SU $369 \mathrm{~B} / 3$ & & $\operatorname{xxxx}$ & $\mathrm{xx}$ & $\mathrm{x}$ & & & & & & & & & & \\
\hline SU 369/29 & & $\mathrm{xxxx}$ & $\mathrm{xxx}$ & $\operatorname{tr}$ & & $\operatorname{tr}$ & & $\operatorname{tr}$ & & & & & & \\
\hline MS63 & MS & $\operatorname{xxxx}$ & & $\mathrm{xxx}$ & $\mathrm{xx}$ & $\mathrm{x}$ & & & & & $\operatorname{tr}$ & & & $\operatorname{tr}$ \\
\hline MS140 & & $\operatorname{xxxx}$ & & $\mathrm{xx}$ & $\mathrm{x}$ & $\mathrm{x}$ & $\operatorname{tr}$ & & & & & & & $\operatorname{tr}$ \\
\hline MS166 & & $\operatorname{xxxx}$ & & $\mathrm{x}$ & $\mathrm{x}$ & $\mathrm{x}$ & $\operatorname{tr}$ & & & & $\operatorname{tr}$ & & & $\operatorname{tr}$ \\
\hline MS119 & & $\mathrm{xxxx}$ & & $\mathrm{xxx}$ & $\mathrm{xx}$ & $\mathrm{x}$ & & & & & & & & $\operatorname{tr}$ \\
\hline MS210 & & $\mathrm{xxxx}$ & & $\mathrm{xxx}$ & $\mathrm{x}$ & $\mathrm{x}$ & $\operatorname{tr}$ & & & & $\operatorname{tr}$ & & & $\operatorname{tr}$ \\
\hline MS26 & & $\mathrm{xxxx}$ & $\operatorname{tr}$ & $\mathrm{xxx}$ & $\mathrm{xx}$ & $\mathrm{x}$ & $\operatorname{tr}$ & & & & & & & $\operatorname{tr}$ \\
\hline MS236 & & $\mathrm{xxxx}$ & & $\mathrm{xxx}$ & $\mathrm{xx}$ & $\mathrm{x}$ & $\operatorname{tr}$ & & & & $\operatorname{tr}$ & & & $\operatorname{tr}$ \\
\hline MS9 & & $\mathrm{xxxx}$ & & $\mathrm{xxx}$ & $\mathrm{xx}$ & $\mathrm{x}$ & & & & & & & & $\operatorname{tr}$ \\
\hline MS11 & & $\mathrm{xxxx}$ & $\operatorname{tr}$ & $\mathrm{xx}$ & $\mathrm{xx}$ & $\mathrm{x}$ & $\operatorname{tr}$ & & & & $\operatorname{tr}$ & & & $\operatorname{tr}$ \\
\hline MS151 & & $\mathrm{xxxx}$ & & $\mathrm{xx}$ & $\mathrm{xx}$ & $\mathrm{x}$ & $\operatorname{tr}$ & & & & $\operatorname{tr}$ & & & $\operatorname{tr}$ \\
\hline SG/SS 1 & SG & $\operatorname{xxxx}$ & & \pm & $\mathrm{xx}$ & $\operatorname{tr}$ & \pm & & & & & & & \\
\hline SG/SS 2 & & $\mathrm{xxxx}$ & $\operatorname{tr}$ & $\mathrm{x}$ & $\mathrm{xx}$ & $\mathrm{x}$ & $\mathrm{x}$ & & & & & & & \\
\hline SG/SS 3 & & $\mathrm{xxxx}$ & & $\operatorname{tr}$ & \pm & $\mathrm{xx}$ & $\operatorname{tr}$ & & & & & & & \\
\hline $\mathrm{SG} / \mathrm{SS} 4$ & & $\mathrm{xxxx}$ & & $\mathrm{x}$ & $\mathrm{x}$ & $\mathrm{xx}$ & \pm & & & & & & & \\
\hline SG/SS 9 & & $\mathrm{xxxx}$ & & $\mathrm{x}$ & $\mathrm{x}$ & \pm & $\operatorname{tr}$ & & & & & & & $\operatorname{tr}$ \\
\hline SGT 1 & & $\mathrm{xxxx}$ & & $\mathrm{x}$ & $\mathrm{x}$ & $\mathrm{xx}$ & & & & & & & & \\
\hline SGT2 & & $\mathrm{xxxx}$ & & $\mathrm{x}$ & $\mathrm{x}$ & \pm & $\mathrm{x}$ & & & & & & & \\
\hline SGT 12 & & $\operatorname{xxxx}$ & & $\mathrm{x}$ & $\mathrm{xx}$ & $x x$ & & & & & & & & $\operatorname{tr}$ \\
\hline SGT 15 & & $\mathrm{xxxx}$ & & $\mathrm{x}$ & $\mathrm{xx}$ & $\mathrm{xx}$ & & & & & & & & \\
\hline SGT 19 & & $\operatorname{xxxx}$ & & $\mathrm{x}$ & $\mathrm{x}$ & $\mathrm{x}$ & & & & & & & & $\operatorname{tr}$ \\
\hline SGT 22 & & $\operatorname{xxxx}$ & & $\mathrm{x}$ & $\mathrm{xx}$ & $\mathrm{xx}$ & & & & & & & & \\
\hline THT94/22/6-1 & TH1 & $\operatorname{xxxx}$ & $\mathrm{xxx}$ & $\mathrm{x}$ & $\mathrm{xx}$ & $\mathrm{xx}$ & & $\operatorname{tr}$ & & & & & & \\
\hline THT 94/18/8-3 & & $\mathrm{xxxx}$ & $\mathrm{xx}$ & $\mathrm{x}$ & $\mathrm{xx}$ & $\mathrm{x}$ & & & & & & & & \\
\hline THT 94/47/5-1 & & $\mathrm{xxxx}$ & $\mathrm{xxx}$ & $\mathrm{x}$ & $\mathrm{x}$ & $\mathrm{xx}$ & & & & $\operatorname{tr}$ & & & & \\
\hline THT 94/10/10-1 & & $\mathrm{xxxx}$ & $\mathrm{xx}$ & $\mathrm{xx}$ & $\mathrm{xx}$ & $\operatorname{tr}$ & & $\operatorname{tr}$ & & & & & & \\
\hline THT 94/18/8-2 & & $\mathrm{xxxx}$ & $\mathrm{xx}$ & $\mathrm{xx}$ & $\mathrm{xx}$ & $\operatorname{tr}$ & & & & $\operatorname{tr}$ & & & & \\
\hline THT 94/5/9-4 & & $\mathrm{xxxx}$ & $\mathrm{xx}$ & $\mathrm{xx}$ & $\mathrm{xxx}$ & $\mathrm{x}$ & & & & & & & & \\
\hline THT 94/2/8-3 & & $\mathrm{xxxx}$ & $\mathrm{xx}$ & $\mathrm{x}$ & $\mathrm{x}$ & $\mathrm{x}$ & & & & & & & & \\
\hline ТHT 94/5/9-1 & & $\mathrm{xxxx}$ & $\mathrm{x}$ & $\mathrm{x}$ & $\mathrm{xx}$ & $\mathrm{x}$ & & $\operatorname{tr}$ & & $\operatorname{tr}$ & & & & \\
\hline THT 94/18/5-2 & & $\mathrm{xxxx}$ & $\mathrm{xxxx}$ & $\mathrm{xx}$ & $\mathrm{xxx}$ & $\mathrm{xx}$ & & $\operatorname{tr}$ & & $\operatorname{tr}$ & & & & \\
\hline ТНТ 94/2/8-4 & & $\operatorname{xxxx}$ & $\operatorname{xxxx}$ & $\mathrm{x}$ & $\mathrm{x}$ & $\mathrm{xx}$ & & $\mathrm{x}$ & & & & & & \\
\hline
\end{tabular}


Table 3 (continued)

\begin{tabular}{|c|c|c|c|c|c|c|c|c|c|c|c|c|c|c|}
\hline Sample & Group & Q & $\mathrm{C}$ & $\mathrm{K}-\mathrm{F}$ & Pl & $\mathrm{I} / \mathrm{M}$ & $\mathrm{Px}$ & $\mathrm{Ge}$ & W & $\mathrm{Fe}-\mathrm{Ox}$ & $\mathrm{Cr}$ & $\mathrm{Cl}$ & Ky & $\mathrm{He}$ \\
\hline THT 94/2/8-1 & $\mathrm{TH} 2$ & $\mathrm{xxxx}$ & $\operatorname{tr}$ & $\mathrm{xx}$ & $\mathrm{xx}$ & & $\mathrm{xx}$ & $\operatorname{tr}$ & $\operatorname{tr}$ & & & & & \\
\hline ТНТ 94/14/10-1 & & $\operatorname{xxxx}$ & $\operatorname{tr}$ & $\mathrm{xx}$ & $\mathrm{xx}$ & & $\mathrm{xx}$ & $\mathrm{xx}$ & $\mathrm{x}$ & & & & & \\
\hline PI2 & $\mathrm{C} 2$ & $\mathrm{xxxx}$ & $\mathrm{xxx}$ & $\operatorname{tr}$ & & $\operatorname{tr}$ & & & & & & & & \\
\hline PI10 & & $\mathrm{xxxx}$ & $\operatorname{xxxx}$ & & & $\operatorname{tr}$ & & & & & & & & \\
\hline PI12 & $\mathrm{C} 1$ & $\mathrm{xxxx}$ & $\operatorname{xxxx}$ & $\operatorname{tr}$ & $\operatorname{tr}$ & $\operatorname{tr}$ & & $\operatorname{tr}$ & & & & & & \\
\hline PI14 & & $\mathrm{xxxx}$ & $\mathrm{xxxx}$ & $\operatorname{tr}$ & $\operatorname{tr}$ & $\operatorname{tr}$ & & & & & & & & \\
\hline
\end{tabular}

$x x x x x$ very abundant, $x x x$ abundant, $x x$ slightly abundant, $x$ low, $t r$ traces

$Q$ quartz, $C$ calcite, $K$ - $F$ K-feldspar, $P l$ plagioclase, $I / M$ illite/montmorillonite, $P x$ pyroxenes, $G e$ gehlenite, $W$ wairakite, $F e$ - $O x$ iron oxides, $C r$ cristobalite, $\mathrm{He}$ hematite, $\mathrm{Cl}$ chlorite, $\mathrm{Ky}$ kyanite

chert, bioclasts, opaque minerals, hematite, feldspar and polycrystalline quartz.

The XRD analysis confirms the existence of two different sample groups. The $\mathrm{T} 1$ group samples are constituted mainly of quartz with some calcite, plagioclases, mica/illite, chlorite and kyanite. The $\mathrm{T} 2$ group samples are composed of quartz, calcite and K-feldspars; sometimes, plagioclase and haematite are present (Table 3). The mineralogical qualitative composition (in particular the presence of carbonate rocks fragments) and the matrix anisotropy indicate in general a low firing temperature for both groups, estimated to be about $750{ }^{\circ} \mathrm{C}$.

The difference already evidenced between the two petrographic groups reflects also in the chemical composition for almost all the oxides (XRF data, Table 4). Even if globally a wide variation in the chemical data is present, by considering singly groups $\mathrm{T} 1$ and $\mathrm{T} 2$, a good homogeneity in between the single group can be evidenced. The samples of T1 group are characterized by a medium alumina content (average value of $15.9 \%$ with standard deviation of $0.97 \%$ ), medium $\mathrm{CaO}$ concentrations (average value of $7.1 \%$ with standard deviation of $1.15 \%)$, and also by high $\mathrm{MnO}(0.12 \%$ average), potassium ( $2.84 \%$ average) and medium to high iron (6.5\% average). The $\mathrm{T} 2$ group samples are characterised by a quite high $\mathrm{CaO}$ content (average value of $15.4 \%$ and standard deviation of $1.14 \%$ ), medium to low alumina concentrations (average value of $10.1 \%$ and standard deviation of $1.13 \%$ ) and medium iron content (average value of $4.59 \%$ and standard deviation of $0.29 \%$ ). The chemical data for this group are different from the one of the T1 group samples and with average values rather similar to the previous samples from Carthage.

By using simple binary correlations $\left(\mathrm{Al}_{2} \mathrm{O}_{3}-\mathrm{K}_{2} \mathrm{O}\right.$; Fig. 7), the presence of two clearly distinct groupings is evident. In the Toscanos samples, the correlation between $\mathrm{CaO}$ and $\mathrm{LOI}$ is rather constant, suggesting more homogeneous pastes and confirming the firing temperatures indicated before; only one sample (TO727) shows relatively low LOI contents also because of a higher presence of Ca-plagioclase.
On the basis of the archaeometric results on the Toscanos samples and concerning the typological study carried out on the ceramics imported from Carthage (T2) (plate P2; cup CCc1; base B3; lamp L2), it is possible to hypothesise that Carthaginian imports arrived in Toscanos not before the half of the seventh century BC.

\section{Sulci samples}

Thanks to archaeometric investigations on Sulci ceramic, the existence of two groups was highlighted (Figs. 8a, b). The group samples differ primarily for the mineralogical composition of the aplastic and secondarily for the abundance of the skeleton, both total and relative to the individual grain size fractions. The matrix is anisotropic for all samples, except one sample where it is in part semi-isotropic.

In the first group (S1), with nine samples, the skeleton is composed of monocrystalline quartz, more rarely polycrystalline; K-feldspar and plagioclases sometimes quite altered, mica more or less abundant; opaque minerals; chert and hematite. Metamorphic rock fragments are found in five samples, one of which is with fragments of volcanic rocks of andesitic type. Sedimentary rock fragments (sandstones and siltstones) are present in four samples. The samples of this group show generally a hiatal aplastic grain size distribution with fine and medium sandy fraction abundance. The aplastic abundance ranges between 5 and $10 \%$. The second group (S2), with five samples, shows a $15-20 \%$ skeleton abundance. The aplastic are composed of monocrystalline quartz, carbonate rock fragments, bioclasts, K-feldspar, chert, hematite and opaque minerals. The hiatal grain size distribution of aplastic is more represented from fine and very sandy fine fractions.

From the XRD analyses results (Table 3), it was possible to distinguish the two groups identified on the basis of their mineral-petrographic characteristic; plagioclases, pyroxenes and cristobalite are exclusive of the first group, while calcite is present only in the second group. In all of the samples, a 
Table 4 Chemical composition of ceramic samples (\%)

\begin{tabular}{|c|c|c|c|c|c|c|c|c|c|c|c|c|}
\hline Sample & Group & LOI & $\mathrm{Na}_{2} \mathrm{O}$ & $\mathrm{MgO}$ & $\mathrm{Al}_{2} \mathrm{O}_{3}$ & $\mathrm{SiO}_{2}$ & $\mathrm{P}_{2} \mathrm{O}_{5}$ & $\mathrm{~K}_{2} \mathrm{O}$ & $\mathrm{CaO}$ & $\mathrm{TiO}_{2}$ & $\mathrm{MnO}$ & $\mathrm{Fe}_{2} \mathrm{O}_{3}$ \\
\hline CA 435 & \multirow[t]{13}{*}{$\mathrm{C} 1$} & 10.98 & 0.42 & 1.64 & 11.74 & 48.10 & 0.37 & 1.60 & 19.20 & 0.72 & 0.03 & 5.21 \\
\hline CA 1183 & & 17.61 & 0.54 & 1.04 & 9.93 & 42.77 & 0.49 & 1.65 & 19.95 & 0.60 & 0.02 & 5.39 \\
\hline CA 1439 & & 16.09 & 0.48 & 1.10 & 10.64 & 46.78 & 0.55 & 1.64 & 17.54 & 0.62 & 0.03 & 4.54 \\
\hline CA 1622 & & 14.95 & 0.57 & 1.12 & 9.79 & 45.40 & 0.54 & 1.70 & 20.43 & 0.63 & 0.03 & 4.86 \\
\hline CA 221 & & 16.80 & 0.63 & 1.20 & 10.25 & 41.59 & 0.31 & 1.74 & 21.97 & 0.59 & 0.04 & 4.87 \\
\hline CA1204 & & 14.65 & 0.57 & 1.17 & 10.48 & 43.61 & 0.53 & 1.77 & 21.48 & 0.63 & 0.03 & 5.07 \\
\hline CA 1216 & & 18.37 & 0.46 & 1.54 & 10.88 & 41.95 & 0.34 & 1.71 & 19.81 & 0.61 & 0.02 & 4.31 \\
\hline CA 1447 & & 16.95 & 0.37 & 1.18 & 10.07 & 45.65 & 0.44 & 1.57 & 18.64 & 0.62 & 0.02 & 4.49 \\
\hline CA 1456 & & 19.29 & 0.19 & 1.52 & 9.47 & 41.41 & 0.23 & 1.50 & 20.93 & 0.57 & 0.03 & 4.84 \\
\hline CA 615 & & 18.11 & 0.40 & 1.21 & 9.77 & 43.82 & 0.20 & 1.58 & 19.82 & 0.60 & 0.02 & 4.46 \\
\hline CA 1075 & & 18.37 & 0.48 & 1.26 & 9.16 & 43.29 & 0.23 & 1.70 & 20.83 & 0.55 & 0.03 & 4.10 \\
\hline CA 152 & & 15.49 & 0.56 & 1.29 & 11.67 & 44.14 & 0.34 & 1.57 & 19.15 & 0.65 & 0.04 & 5.10 \\
\hline CA 1013 & & 13.83 & 0.47 & 1.30 & 12.21 & 45.44 & 0.18 & 1.73 & 19.04 & 0.69 & 0.05 & 5.06 \\
\hline CA 888 & \multirow[t]{14}{*}{$\mathrm{C} 2$} & 4.46 & 0.50 & 1.51 & 12.02 & 58.83 & 0.66 & 1.42 & 14.40 & 0.72 & 0.03 & 5.44 \\
\hline CA 34 & & 11.91 & 0.45 & 1.36 & 12.78 & 53.19 & 0.21 & 1.74 & 12.72 & 0.69 & 0.03 & 4.92 \\
\hline CA 35 & & 13.67 & 0.30 & 1.16 & 11.93 & 51.25 & 0.23 & 1.66 & 14.14 & 0.68 & 0.03 & 4.95 \\
\hline CA 1685 & & 6.64 & 0.60 & 1.55 & 12.19 & 56.98 & 0.40 & 1.72 & 13.71 & 0.73 & 0.04 & 5.45 \\
\hline CA 1184 & & 6.30 & 0.38 & 1.56 & 12.20 & 56.32 & 0.24 & 1.42 & 15.96 & 0.66 & 0.03 & 4.93 \\
\hline CA 1576 & & 14.94 & 0.39 & 1.41 & 11.69 & 47.39 & 0.31 & 1.61 & 16.75 & 0.66 & 0.03 & 4.83 \\
\hline CA 1126 & & 14.38 & 0.28 & 1.43 & 12.56 & 50.08 & 0.23 & 1.55 & 13.71 & 0.67 & 0.02 & 5.09 \\
\hline CA 64 & & 14.09 & 0.52 & 1.33 & 11.01 & 50.36 & 0.40 & 1.50 & 15.37 & 0.59 & 0.03 & 4.80 \\
\hline CA 1049 & & 12.99 & 0.45 & 1.41 & 12.32 & 51.51 & 0.18 & 1.57 & 13.44 & 0.69 & 0.03 & 5.40 \\
\hline CA 1573 & & 12.27 & 0.40 & 1.45 & 11.52 & 52.86 & 0.18 & 1.66 & 14.01 & 0.65 & 0.03 & 4.98 \\
\hline CA 217 & & 9.82 & 0.51 & 1.40 & 12.51 & 53.84 & 0.25 & 1.74 & 14.15 & 0.72 & 0.04 & 5.02 \\
\hline CA 184 & & 13.74 & 0.55 & 1.34 & 11.50 & 50.29 & 0.30 & 1.68 & 15.22 & 0.63 & 0.02 & 4.74 \\
\hline CA 3 & & 11.91 & 0.48 & 1.54 & 11.41 & 50.73 & 0.21 & 1.66 & 16.53 & 0.64 & 0.03 & 4.86 \\
\hline CA 124 & & 12.70 & 0.55 & 1.43 & 11.11 & 52.80 & 0.25 & 1.55 & 14.46 & 0.65 & 0.03 & 4.47 \\
\hline CA 295 & \multirow[t]{5}{*}{ isolated } & 12.21 & 0.70 & 1.39 & 10.35 & 45.92 & 0.68 & 1.59 & 21.56 & 0.64 & 0.03 & 4.94 \\
\hline CA 297 & & 16.74 & 0.49 & 1.91 & 12.48 & 44.32 & 0.41 & 1.56 & 16.37 & 0.70 & 0.02 & 5.00 \\
\hline CA 605 & & 9.75 & 0.48 & 1.50 & 11.13 & 52.50 & 0.25 & 1.46 & 17.34 & 0.63 & 0.03 & 4.93 \\
\hline CA 757 & & 9.25 & 0.43 & 1.67 & 13.41 & 56.91 & 0.24 & 1.77 & 10.22 & 0.76 & 0.04 & 5.31 \\
\hline CA 1590 & & 7.31 & 0.51 & 1.64 & 12.11 & 49.66 & 0.30 & 1.42 & 21.04 & 0.68 & 0.05 & 5.28 \\
\hline TO 862 & \multirow[t]{13}{*}{$\mathrm{T} 1$} & 4.97 & 0.77 & 2.71 & 15.44 & 58.52 & 0.32 & 2.79 & 6.87 & 0.85 & 0.11 & 6.65 \\
\hline TO 570 & & 3.69 & 0.82 & 3.07 & 16.33 & 57.91 & 0.41 & 2.90 & 7.16 & 0.89 & 0.12 & 6.69 \\
\hline TO 674 & & 2.67 & 0.78 & 2.94 & 17.05 & 58.11 & 0.46 & 2.87 & 7.40 & 0.90 & 0.11 & 6.71 \\
\hline TO 689 & & 5.26 & 0.73 & 2.79 & 16.36 & 57.23 & 0.38 & 2.89 & 7.00 & 0.85 & 0.11 & 6.40 \\
\hline TO 702 & & 8.69 & 0.49 & 2.49 & 14.56 & 55.95 & 0.18 & 2.55 & 7.93 & 0.83 & 0.10 & 6.23 \\
\hline TO 63 & & 4.23 & 0.74 & 2.93 & 16.03 & 60.10 & 0.24 & 3.05 & 5.09 & 0.91 & 0.09 & 6.61 \\
\hline TO 667 & & 5.01 & 0.63 & 2.90 & 16.45 & 56.09 & 0.23 & 2.81 & 9.02 & 0.85 & 0.09 & 5.92 \\
\hline TO 727 & & 7.05 & 0.62 & 3.37 & 14.83 & 58.49 & 0.27 & 2.83 & 5.12 & 0.87 & 0.11 & 6.43 \\
\hline TO 13 & & 5.47 & 0.36 & 2.27 & 14.56 & 58.79 & 0.34 & 2.30 & 8.68 & 0.89 & 0.13 & 6.21 \\
\hline TO 86 & & 3.93 & 0.99 & 2.83 & 16.82 & 57.71 & 0.36 & 3.19 & 6.44 & 0.91 & 0.11 & 6.69 \\
\hline TO 87 & & 7.52 & 0.38 & 2.43 & 14.59 & 56.73 & 0.75 & 2.78 & 7.55 & 0.88 & 0.15 & 6.25 \\
\hline TO 108 & & 4.19 & 0.58 & 2.89 & 16.96 & 56.43 & 0.57 & 3.09 & 6.97 & 0.88 & 0.18 & 7.25 \\
\hline TO 478 & & 3.45 & 0.76 & 3.04 & 16.68 & 57.81 & 0.53 & 2.88 & 7.44 & 0.86 & 0.11 & 6.46 \\
\hline TO 391 & \multirow[t]{4}{*}{$\mathrm{T} 2$} & 15.37 & 0.15 & 1.42 & 9.74 & 51.65 & 0.30 & 1.25 & 14.83 & 0.60 & 0.04 & 4.65 \\
\hline TO 584 & & 16.73 & 0.21 & 1.24 & 8.44 & 51.60 & 0.29 & 1.07 & 15.65 & 0.61 & 0.04 & 4.12 \\
\hline TO 180 & & 13.02 & 0.21 & 1.24 & 11.62 & 51.64 & 0.72 & 1.72 & 14.13 & 0.68 & 0.04 & 4.98 \\
\hline TO 212 & & 16.38 & 0.25 & 1.53 & 10.88 & 46.25 & 0.78 & 1.43 & 17.09 & 0.64 & 0.04 & 4.74 \\
\hline
\end{tabular}


Table 4 (continued)

\begin{tabular}{|c|c|c|c|c|c|c|c|c|c|c|c|c|}
\hline Sample & Group & LOI & $\mathrm{Na}_{2} \mathrm{O}$ & $\mathrm{MgO}$ & $\mathrm{Al}_{2} \mathrm{O}_{3}$ & $\mathrm{SiO}_{2}$ & $\mathrm{P}_{2} \mathrm{O}_{5}$ & $\mathrm{~K}_{2} \mathrm{O}$ & $\mathrm{CaO}$ & $\mathrm{TiO}_{2}$ & $\mathrm{MnO}$ & $\mathrm{Fe}_{2} \mathrm{O}_{3}$ \\
\hline TO 508 & & 15.75 & 0.38 & 1.33 & 9.19 & 50.38 & 0.63 & 1.46 & 15.84 & 0.59 & 0.03 & 4.41 \\
\hline TO 904 & & 14.78 & 0.28 & 1.28 & 9.78 & 53.11 & 0.42 & 1.36 & 13.99 & 0.57 & 0.03 & 4.41 \\
\hline TO 328 & & 15.10 & 0.40 & 1.62 & 11.08 & 47.16 & 0.92 & 1.88 & 16.26 & 0.71 & 0.04 & 4.81 \\
\hline SU 369/142 & $\mathrm{S} 1$ & 3.84 & 1.35 & 1.50 & 17.09 & 65.00 & 0.05 & 3.08 & 1.30 & 0.69 & 0.05 & 6.06 \\
\hline SU 369/143/45 & & 3.94 & 1.61 & 1.08 & 16.34 & 66.71 & 0.06 & 3.55 & 1.13 & 0.61 & 0.08 & 4.89 \\
\hline SU 369/167 & & 3.63 & 1.69 & 0.96 & 15.97 & 67.37 & 0.06 & 3.83 & 1.16 & 0.58 & 0.09 & 4.66 \\
\hline SU 369/182 & & 2.11 & 2.32 & 0.65 & 16.88 & 68.37 & 0.06 & 3.81 & 1.25 & 0.51 & 0.04 & 4.01 \\
\hline SU 369B/75 & & 4.42 & 1.43 & 1.19 & 15.76 & 66.61 & 0.04 & 3.31 & 1.27 & 0.63 & 0.09 & 5.24 \\
\hline SU 369/32 & & 3.03 & 2.10 & 0.87 & 15.55 & 68.71 & 0.07 & 3.70 & 0.97 & 0.51 & 0.04 & 4.44 \\
\hline SU 369/46 & & 4.22 & 2.18 & 0.75 & 17.44 & 65.63 & 0.06 & 3.51 & 1.46 & 0.49 & 0.06 & 4.20 \\
\hline SU 369B/10 & & 4.52 & 1.42 & 1.38 & 16.68 & 64.96 & 0.07 & 3.39 & 1.39 & 0.66 & 0.09 & 5.44 \\
\hline SU 369B/21 & & 4.07 & 1.27 & 1.58 & 17.36 & 64.67 & 0.05 & 3.03 & 1.28 & 0.68 & 0.05 & 5.96 \\
\hline SU 369B/56 & & 4.61 & 1.44 & 1.23 & 15.25 & 66.75 & 0.06 & 3.39 & 1.77 & 0.59 & 0.09 & 4.81 \\
\hline SU 369/102 & $\mathrm{S} 2$ & 14.14 & 0.39 & 1.11 & 11.00 & 50.52 & 0.18 & 1.30 & 16.17 & 0.63 & 0.04 & 4.52 \\
\hline SU 369/129 & & 15.82 & 0.36 & 1.29 & 10.49 & 48.85 & 0.15 & 1.26 & 16.71 & 0.59 & 0.03 & 4.45 \\
\hline SU 369/170 & & 6.52 & 0.29 & 1.36 & 11.53 & 58.06 & 0.51 & 1.12 & 14.96 & 0.64 & 0.03 & 4.98 \\
\hline $\mathrm{SU} 369 \mathrm{~B} / 3$ & & 13.83 & 0.25 & 1.33 & 11.38 & 52.28 & 0.14 & 1.13 & 14.53 & 0.62 & 0.04 & 4.47 \\
\hline SU 557/29 & & 14.60 & 0.27 & 1.30 & 11.47 & 49.79 & 0.19 & 1.08 & 15.95 & 0.64 & 0.03 & 4.68 \\
\hline MS 26 & MS & 1.92 & 1.40 & 1.21 & 14.83 & 69.63 & 0.10 & 3.03 & 1.71 & 0.61 & 0.13 & 5.43 \\
\hline MS 166 & & 2.11 & 1.15 & 1.51 & 16.62 & 67.27 & 0.17 & 2.89 & 0.84 & 0.65 & 0.08 & 6.69 \\
\hline MS 210 & & 2.37 & 1.21 & 1.60 & 18.27 & 64.57 & 0.37 & 2.90 & 1.02 & 0.68 & 0.18 & 6.83 \\
\hline MS 9 & & 3.25 & 0.81 & 0.87 & 12.61 & 73.05 & 0.22 & 2.82 & 0.63 & 0.61 & 0.02 & 5.12 \\
\hline MS 63 & & 4.10 & 1.25 & 0.98 & 13.53 & 68.27 & 1.21 & 3.04 & 2.33 & 0.51 & 0.09 & 4.70 \\
\hline MS 119 & & 1.46 & 1.57 & 1.06 & 15.89 & 69.14 & 0.06 & 2.80 & 1.76 & 0.58 & 0.08 & 5.61 \\
\hline MS 151 & & 3.59 & 1.07 & 1.21 & 14.46 & 69.36 & 0.22 & 3.03 & 1.04 & 0.62 & 0.06 & 5.35 \\
\hline MS 236 & & 2.31 & 1.27 & 0.79 & 12.85 & 74.05 & 0.24 & 2.89 & 0.73 & 0.50 & 0.05 & 4.32 \\
\hline MS 11 & & 2.42 & 1.33 & 1.44 & 15.98 & 66.14 & 0.15 & 3.00 & 2.56 & 0.66 & 0.16 & 6.17 \\
\hline MS 140 & & 4.00 & 1.33 & 1.29 & 16.71 & 64.67 & 0.75 & 3.07 & 1.28 & 0.64 & 0.14 & 6.12 \\
\hline SG/SS 1 & SG & 10.15 & 1.53 & 2.86 & 13.18 & 50.83 & 0.34 & 2.25 & 13.17 & 0.62 & 0.04 & 5.02 \\
\hline SG/SS 2 & & 6.60 & 0.84 & 2.94 & 15.77 & 55.05 & 0.34 & 2.70 & 8.96 & 0.76 & 0.04 & 6.00 \\
\hline SG/SS 3 & & 3.25 & 0.83 & 2.33 & 17.27 & 60.55 & 0.38 & 3.81 & 3.99 & 0.87 & 0.04 & 6.69 \\
\hline SG/SS 4 & & 3.67 & 0.92 & 3.00 & 19.05 & 57.49 & 0.21 & 3.37 & 4.63 & 0.92 & 0.04 & 6.71 \\
\hline SG/SS 6 & & 10.39 & 0.77 & 2.75 & 14.33 & 49.53 & 0.16 & 2.88 & 13.46 & 0.67 & 0.03 & 5.04 \\
\hline SG/SS 8 & & 1.92 & 1.60 & 2.85 & 19.42 & 58.67 & 0.65 & 3.38 & 1.63 & 1.37 & 0.06 & 8.45 \\
\hline SG/SS 9 & & 1.44 & 1.50 & 2.59 & 18.68 & 61.88 & 0.14 & 3.87 & 0.95 & 1.04 & 0.09 & 7.83 \\
\hline SGT 1 & & 1.28 & 1.48 & 2.73 & 17.73 & 64.22 & 0.06 & 3.89 & 1.01 & 0.82 & 0.08 & 6.71 \\
\hline SGT 22 & & 1.38 & 1.62 & 2.53 & 17.39 & 64.46 & 0.10 & 3.86 & 1.15 & 0.79 & 0.08 & 6.66 \\
\hline THT94/2/8-3 & TH1 & 8.02 & 1.11 & 2.21 & 14.76 & 50.25 & 0.21 & 2.60 & 15.35 & 0.62 & 0.03 & 4.84 \\
\hline THT 94/5/9-1 & & 5.57 & 1.33 & 2.42 & 15.48 & 52.43 & 0.18 & 2.94 & 13.74 & 0.68 & 0.03 & 5.20 \\
\hline THT 94/5/9-4 & & 7.42 & 1.39 & 2.20 & 13.23 & 56.00 & 0.30 & 2.86 & 11.85 & 0.62 & 0.03 & 4.11 \\
\hline ТHТ 94/2/8-4 & & 3.50 & 1.20 & 2.14 & 13.62 & 51.82 & 0.17 & 2.97 & 19.51 & 0.63 & 0.03 & 4.41 \\
\hline THT 94/10/10-1 & & 9.62 & 1.23 & 2.10 & 12.56 & 51.20 & 0.25 & 2.60 & 15.64 & 0.59 & 0.04 & 4.15 \\
\hline THT 94/18/5-2 & & 15.58 & 1.21 & 1.61 & 10.76 & 47.37 & 0.16 & 2.59 & 16.58 & 0.52 & 0.03 & 3.60 \\
\hline THT 94/18/8-2 & & 8.31 & 1.26 & 2.22 & 13.29 & 53.64 & 0.19 & 2.86 & 13.51 & 0.60 & 0.03 & 4.07 \\
\hline THT 94/18/8-3 & & 7.69 & 1.45 & 2.20 & 13.69 & 51.04 & 0.45 & 2.87 & 15.73 & 0.62 & 0.03 & 4.23 \\
\hline THT 94/22/6-1 & & 13.84 & 1.12 & 2.09 & 12.75 & 48.33 & 0.17 & 2.67 & 14.23 & 0.58 & 0.03 & 4.20 \\
\hline THT 94/47/5-1 & & 11.92 & 1.34 & 2.15 & 13.49 & 49.38 & 0.17 & 3.17 & 13.37 & 0.61 & 0.03 & 4.39 \\
\hline ТHT 94/2/8-1 & TH2 & 2.34 & 1.91 & 2.72 & 17.10 & 54.30 & 0.20 & 2.49 & 12.75 & 0.71 & 0.05 & 5.42 \\
\hline THT 94/14/10-1 & & 4.33 & 2.33 & 2.36 & 16.08 & 51.33 & 0.38 & 1.72 & 15.56 & 0.67 & 0.04 & 5.18 \\
\hline
\end{tabular}


Table 4 (continued)

\begin{tabular}{lcccccccccccc}
\hline Sample & Group & LOI & $\mathrm{Na}_{2} \mathrm{O}$ & $\mathrm{MgO}$ & $\mathrm{Al}_{2} \mathrm{O}_{3}$ & $\mathrm{SiO}_{2}$ & $\mathrm{P}_{2} \mathrm{O}_{5}$ & $\mathrm{~K}_{2} \mathrm{O}$ & $\mathrm{CaO}^{2}$ & $\mathrm{TiO}_{2}$ & $\mathrm{MnO}^{2} \mathrm{Fe}_{2} \mathrm{O}_{3}$ \\
\hline PI 2 & $\mathrm{C} 2$ & 15.24 & 0.48 & 1.38 & 9.21 & 51.77 & 0.14 & 1.30 & 15.69 & 0.56 & 0.03 & 4.20 \\
PI 10 & & 17.34 & 0.48 & 1.29 & 9.95 & 43.63 & 0.16 & 1.20 & 20.62 & 0.63 & 0.02 & 4.69 \\
PI 12 & $\mathrm{C} 1$ & 16.95 & 0.34 & 1.29 & 10.08 & 46.51 & 0.16 & 1.35 & 18.43 & 0.61 & 0.02 & 4.25 \\
PI 14 & & 15.43 & 0.44 & 1.54 & 9.96 & 49.07 & 0.19 & 1.40 & 16.93 & 0.63 & 0.03 & 4.39 \\
\hline
\end{tabular}

large amount of quartz is present together with few illite/ micas.

From the comparison between the mineralogicalpetrographic composition of the two groups (S1 and S2) and the local geological context, it should be noted that only group S1 can be considered as local because its aplastic composition is compatible with the geological formations of the area (Carmignani 1996).

The evaluation of the firing temperature of the local production is quite difficult because of the very low presence of calcium in the raw materials, so the formation of compounds typical of firing is very limited. The small amounts of pyroxenes and gehlenite detected, the presence of illite/mica (Cultrone et al. 2001) and the matrix anisotropy still allow hypothesising firing temperatures around $800{ }^{\circ} \mathrm{C}$. Theoretically, even cristobalite could be newly formed, but its formation requires temperatures around $1050-1100{ }^{\circ} \mathrm{C}$ and certainly cannot have been formed during the firing of these ceramic wares, so this mineral had to be present in the raw materials. In case the temperature is higher than $1000^{\circ} \mathrm{C}$, gehlenite reacts and forms two other phases such as calcium pyroxene (wollastonite) and plagioclase (anorthite) (Padeletti and Fermo 2010). The firing temperature of the S2 ceramic group can be estimated around $750{ }^{\circ} \mathrm{C}$, since calcite is present in abundant amounts in all samples, while pyroxene and gehlenite are absent or in traces.
The chemical analysis (XRF) carried out on Sulci samples (Table 4) confirm the existence of two groups: the first group (S1) shows high levels of $\mathrm{SiO}_{2}\left(66.48 \%\right.$ average), $\mathrm{Al}_{2} \mathrm{O}_{3}$ ( $16.43 \%$ average), $\mathrm{Na}_{2} \mathrm{O}$ ( $1.68 \%$ average) and $\mathrm{K}_{2} \mathrm{O}$ (16.43\% average), while $\mathrm{CaO}$ is very low $(1.30 \%$ average). The second group (S2) presents a lower content of $\mathrm{SiO}_{2}$ (51.9\% average), $\mathrm{Al}_{2} \mathrm{O}_{3}$ (11.17\% average), $\mathrm{Na}_{2} \mathrm{O}$ $(0.31 \%$ average $)$ and $\mathrm{K}_{2} \mathrm{O}(1.18 \%$ average $)$, while the concentrations of $\mathrm{CaO}$ are higher (15.66\% average). The sample isolated from the mineralogical and petrographic point of view fits within group S1. The standard deviation in between the single group considered is restrained, attesting a possible common provenance for the samples belonging to the same group. By using simple binary correlations $\left(\mathrm{Al}_{2} \mathrm{O}_{3}-\mathrm{K}_{2} \mathrm{O}\right.$; Fig. 9), the presence of two clearly distinct groupings ( $\mathrm{S} 1$ and $\mathrm{S} 2$ ) is evident.

By considering the CaO-LOI ratio, most of the Sulci samples seem to have the same characteristics with the exception of one sample (S 369/170, cup belonging to the S2), characterized by a lower LOI content related to the plagioclase presence. The chemical data confirm the suggested firing temperature $\left(800^{\circ} \mathrm{C}\right)$, since the neoformation of gehlenite observed by XRD should be at the very beginning and did not affect much the CaO-LOI ratio.

The archaeometric investigations carried out on Sulci samples allowed identification of two main pottery groups: the
Fig. $4 \mathrm{MgO}-\mathrm{CaO}$ binary correlation diagram; Carthage samples

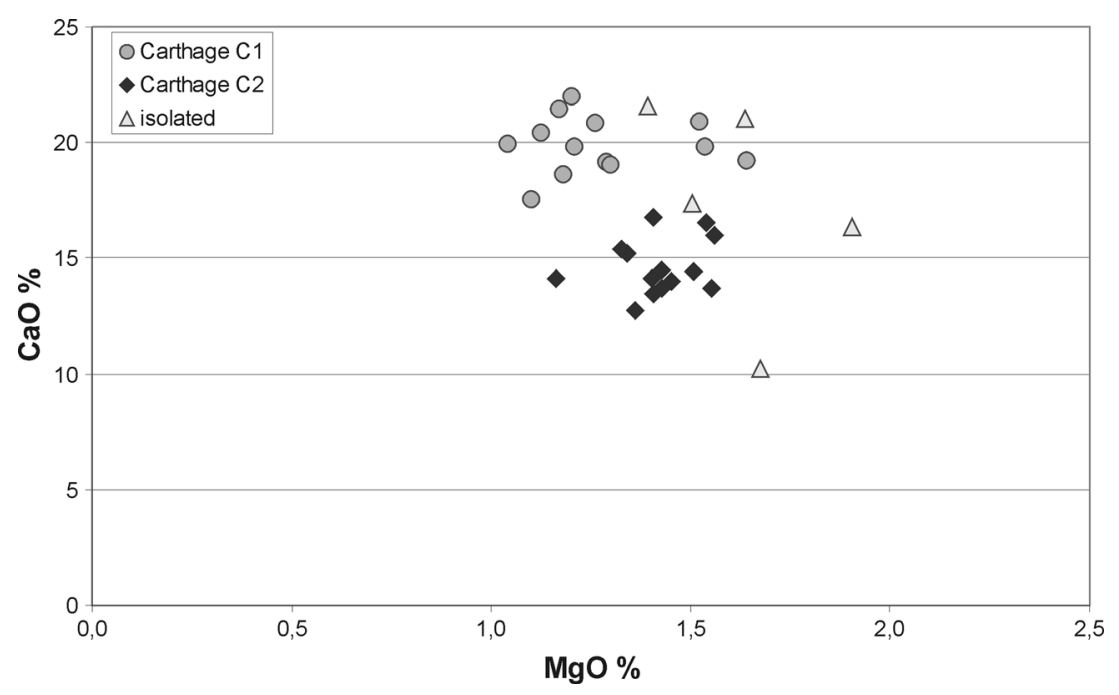


Fig. 5 CaO-LOI binary correlation diagram; Carthage samples

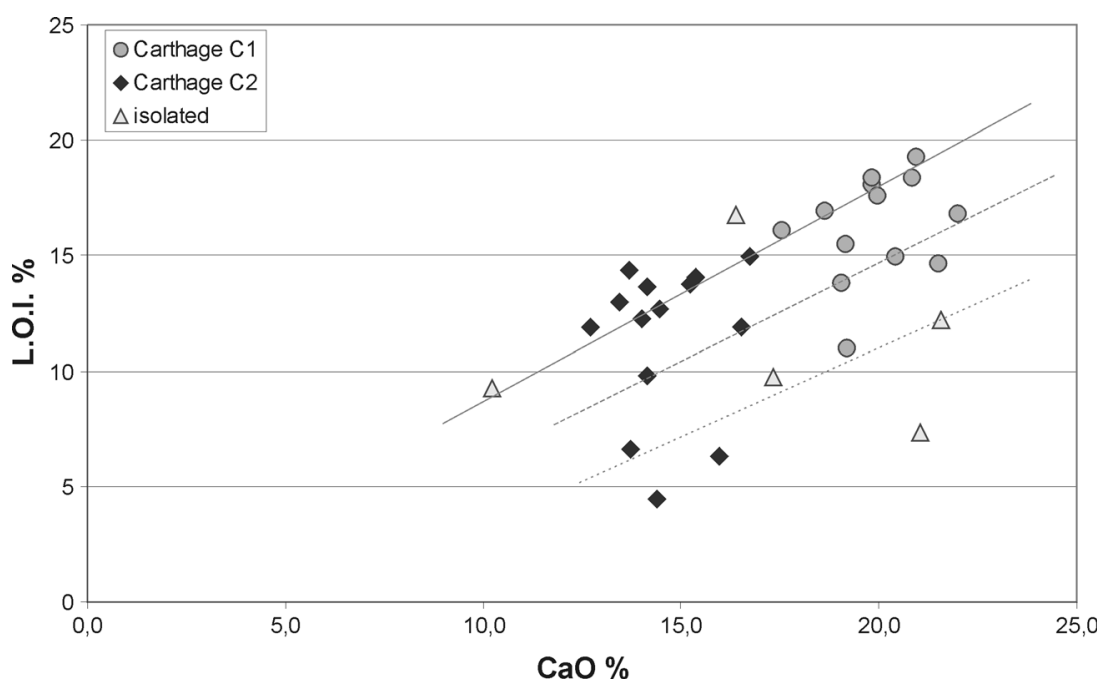

first is considered local (S1) and the other (S2) was considered imported from Carthage and presents characters compatible with the $\mathrm{C} 2$ group (plate $\mathrm{P} 1$; cups $\mathrm{CCr} 1, \mathrm{CCc} 1$ ).

\section{Monte Sirai samples}

The mineralogical and petrographic aspects allowed considering these samples a more or less homogeneous group. The matrix is always from anisotropic to semi-isotropic with little clayed aggregates and bonherz (Fig. 10a, b). The aplastic show generally a hiatal grain size distribution with abundance of medium and fine sandy fraction. The samples are composed of monocrystalline and polycrystalline quartz, K-feldspar and plagioclases, sometimes altered and sericitized, metamorphic and sedimentary rock fragments, rare volcanic rock fragments and mica, opaque minerals, hematite and chert. In two samples, there are few fragments of carbonatic rock fragments, almost completely altered because of firing. The samples show variations related to the total amount of aplastic and the abundance of the particle size fraction greater than $500 \mu \mathrm{m}$.

X-ray diffraction analyses show an abundance of quartz, a fair amount of K-feldspar, plagioclases and illite/mica. In some samples, there are traces of cristobalite, hematite and pyroxene. Calcite is nearly always absent, with the exception of two samples which contain only trace amounts. The structural and compositional characteristics allowed hypothesising a firing temperature estimated at around $850{ }^{\circ} \mathrm{C}$.

Monte Sirai samples from the chemical point of view (Table 4) are characterised by the presence of very low quantities of $\mathrm{CaO}$ (1.39\% average), by high levels of $\mathrm{SiO}_{2}$ (68.68\% average) and by medium alumina concentrations (average value of $15.17 \%$ ). Monte Sirai samples show a general chemical affinity with the local group (S1) of Sulci samples, from which they differ mainly in the $\mathrm{K}_{2} \mathrm{O}$ content (average value of $2.95 \%$ ). Since Monte Sirai samples have low $\mathrm{CaO}$ content and only in two samples calcite in traces has been found by XRD, only a weak correlation with the LOI is present.
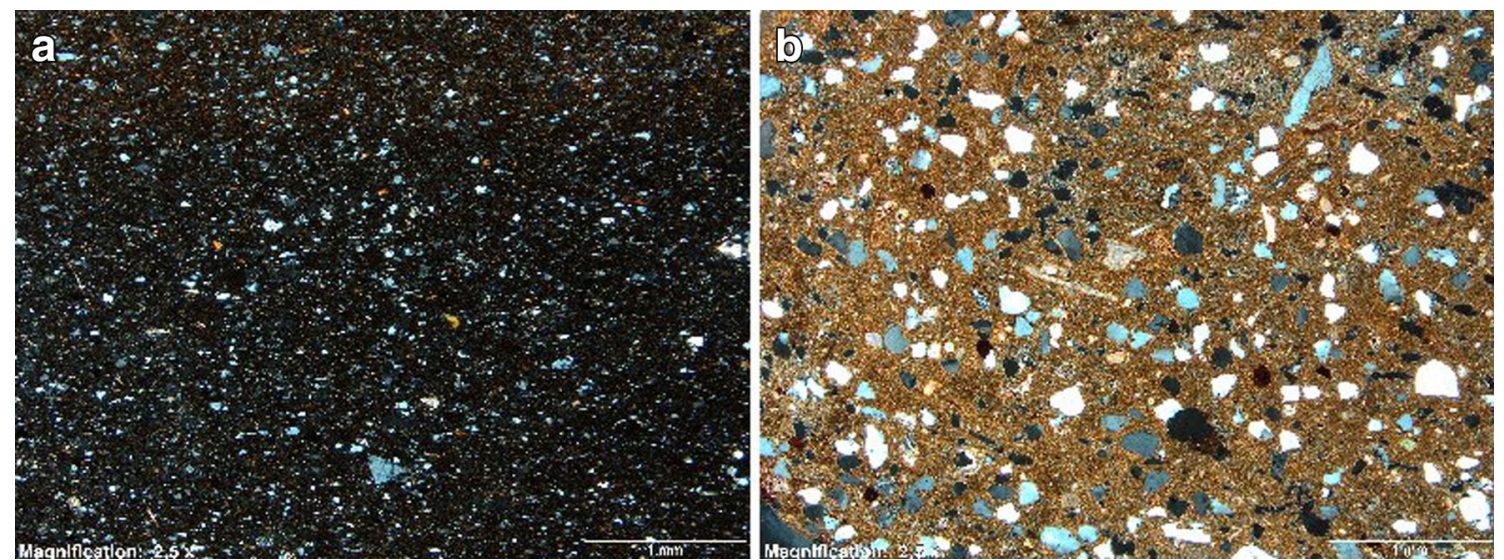

Fig. 6 a Sample TO 391, transmitted light micrograph, XPL, T2 group. Plate, Toscanos (imported); b sample TO 674, transmitted light micrograph, XPL, T1 group. Plate, Toscanos (local) 
Fig. $7 \quad \mathrm{Al}_{2} \mathrm{O}_{3}-\mathrm{K}_{2} \mathrm{O}$ binary correlation diagram, Toscanos samples

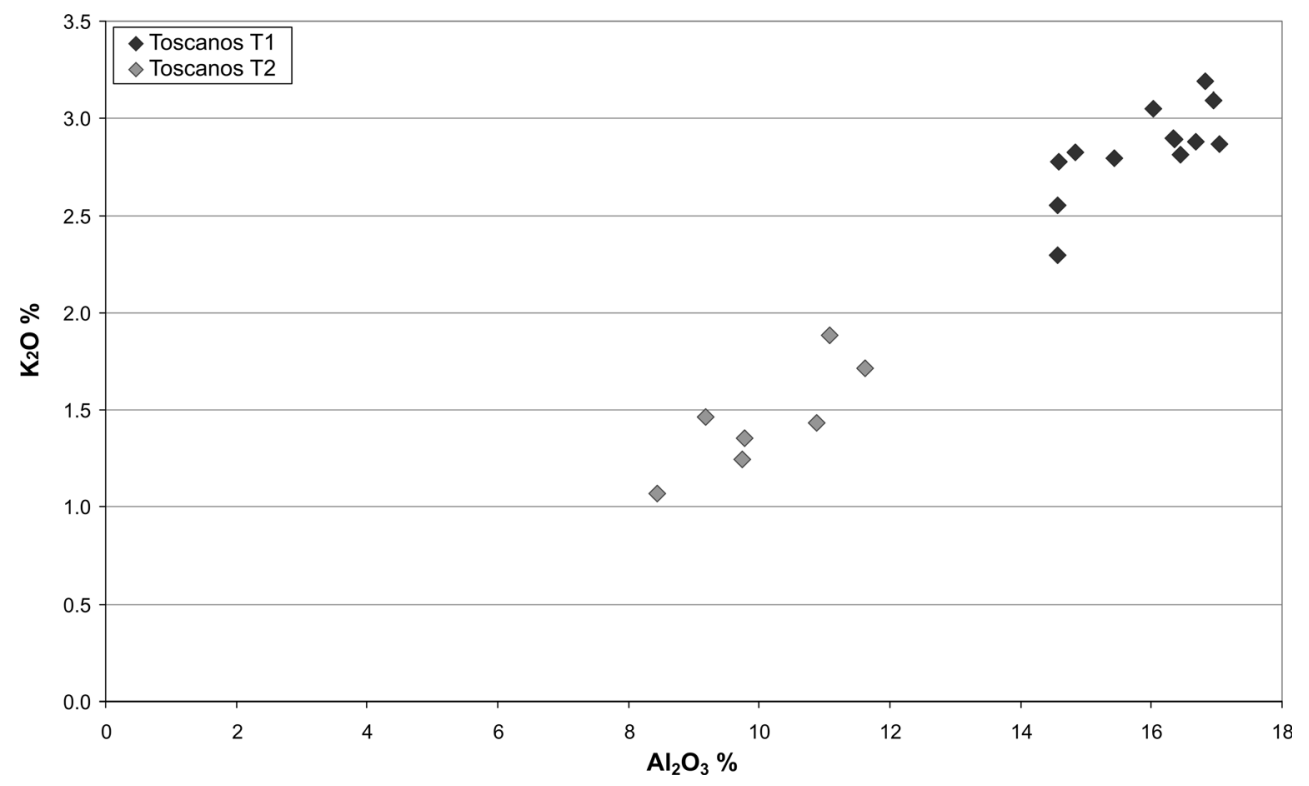

The typological study of Monte Sirai ceramics supposed that the pottery was of local production.

\section{Othoca samples}

Concerning mineralogical and petrographic characteristics, the samples from Othoca were classified in four groups. Group O1 (samples SG/SS 1, SG/SS 2 and SG/SS 6; Fig. 11a) is characterised by an anisotropic matrix and a hiatal grain size distribution with abundance of silty fraction associated to scarce larger fractions. The aplastic are represented by intrusive rocks fragments, monocrystalline and polycrystalline quartz, mica, feldspar, hematite and opaque minerals. The abundance ranges between 3 and $10 \%$.

Group O2 (samples SG/SS 8, SG/SS 9 and SGT 1; Fig. 11b) can be considered a more or less homogeneous group with an anisotropic to semi-isotropic matrix. The aplastics have a hiatal grain size distribution with abundance of fine to medium sandy fraction with scarce smaller fractions. The abundance ranges between 15 and $30 \%$. Monocrystalline and polycrystalline quartz, intrusive rock fragments, feldspars and micas generally represent the composition. In the SGT 1 sample, metamorphic rock fragments are present as well. The SG/SS 8 sample has an isotropic matrix; a prevalent fine sandy fraction associated to scarce smaller fractions is present. Metamorphic rock fragments, monocrystalline and polycrystalline quartz, feldspar, micas, opaque mineral and hematite represent the aplastic fraction.

The samples of group O3 (SGT 2, SGT 19, SGT 22, SGT 12, SGT 15, SGT 19; Fig. 11c) show an anisotropic matrix and a serial grain size distribution of aplastic. The abundance ranges generally between 10 and $30 \%$. The SGT 12 and SGT 15 samples are characterized by the presence of monocrystalline and polycrystalline quartz, feldspar and metamorphic rock fragments, micas, opaque minerals and hematite. Sometimes, intrusive rock and sedimentary rock fragments are present (SGT 19).
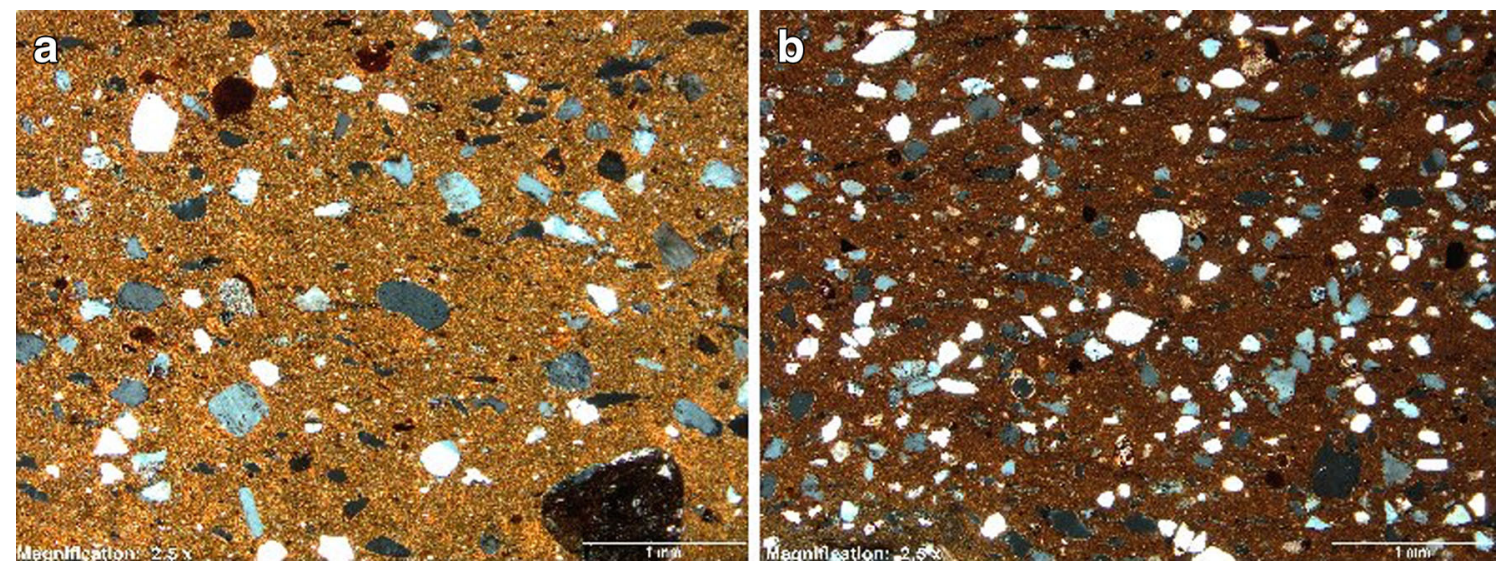

Fig. 8 a Sample SU 369/102, transmitted light micrograph, XPL, S2. Plate, Sulci (imported); b sample SU 369/142, transmitted light micrograph, XPL, S1. Plate, Sulci (local) 
Fig. $9 \mathrm{Al}_{2} \mathrm{O}_{3}-\mathrm{K}_{2} \mathrm{O}$ binary correlation diagram, Sulci samples

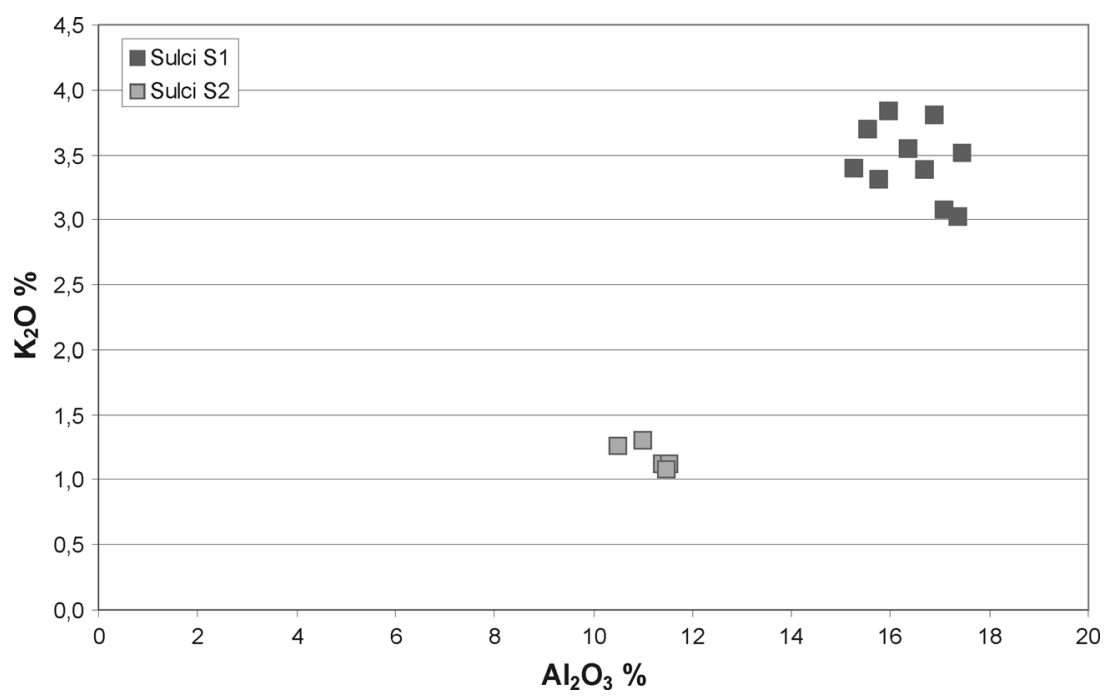

The samples of group O4 (sample SG/SS 3 and SG/SS 4; Fig. 11d) show an isotropic matrix and a prevalent silty and very fine sandy fraction. Intrusive and effusive rock fragments were observed. The matrix abundance ranges between 5 and $10 \%$.

The X-ray diffraction analyses show the presence of one group characterised by the absence of calcite (SGT 1, SGT 22, $\mathrm{SG} / \mathrm{SS} 1, \mathrm{SG} / \mathrm{SS} 3, \mathrm{SG} / \mathrm{SS} 4, \mathrm{SG} / \mathrm{SS}$ 9); quartz, feldspars and illite/mica and sometimes, pyroxenes are present too. The SG/ SS 1 sample is characterized by the presence of gehlenite too. In the SG/SS 2 sample, calcite, quartz, feldspars and illite/ mica are present.

The groupings supported by mineralogical and petrographic composition were confirmed by a strong chemical inhomogeneity and data dispersion (Table 4). The combination of the optical microscopy observations, XRD and XRF analyses results indicate the presence of at least three main groups according to their carbonate content. Since the number of samples for each group is small, no standard deviation has been considered in the following discussion.
The first group is characterised by a medium to high $\mathrm{CaO}$ content (from 8.96 to $13.46 \%$ ) and correspond perfectly to the previously identified group $\mathrm{O} 1$ (from the necropolis). These samples have medium $\mathrm{Al}_{2} \mathrm{O}_{3}$ concentrations (from 13.18 to $15.77 \%$ ), medium to high $\mathrm{K}_{2} \mathrm{O}$ (from 2.25 to $2.88 \%$ ) and medium iron content (from 5.02 to $6.0 \%$ ). A second group is characterised by a medium to low $\mathrm{CaO}$ content (from 3.99 to $4.63 \%$ ) and correspond to the previously identified group $\mathrm{O} 4$ (from the necropolis). These samples have medium to high $\mathrm{Al}_{2} \mathrm{O}_{3}$ concentrations (from 17.27 to $19.05 \%$ ), quite high $\mathrm{K}_{2} \mathrm{O}$ (from 3.37 to $3.81 \%$ ) and medium (but higher with respect to the previous group) $\mathrm{Fe}_{2} \mathrm{O}_{3}$ content (from 6.69 to $6.71 \%$ ). The third group (both from the necropolis and from the Lagoon) is characterised by low $\mathrm{CaO}$ content (from 0.95 to $1.63 \%$ ) and correspond to the previously identified groups $\mathrm{O} 2$ and $\mathrm{O} 3$. Only one sample from the $\mathrm{O} 3$ group has been chemically analysed, and the results indicate that this sample (SGT 22 ) is chemically very similar to the ones of $\mathrm{O} 2$ group. These samples have medium to high $\mathrm{Al}_{2} \mathrm{O}_{3}$ concentrations (from
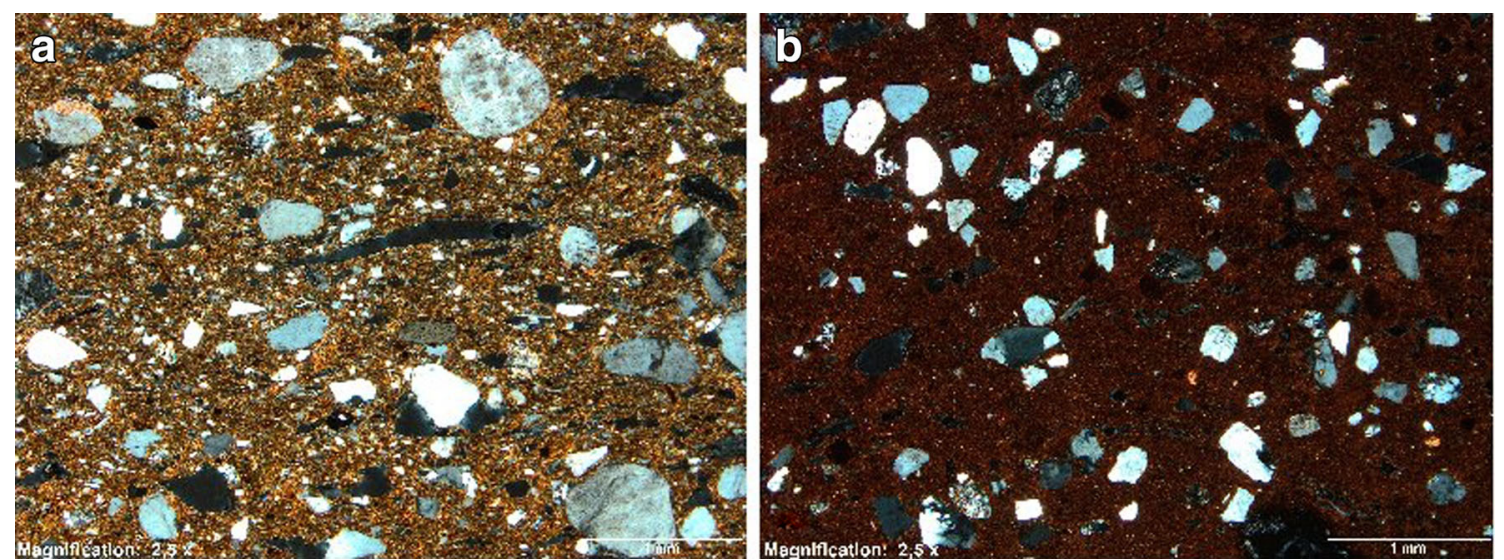

Fig. 10 a Sample MS 151, transmitted light micrograph, XPL. Cup, Monte Sirai (local); b sample MS 210, transmitted light micrograph, XPL. Plate P2, Monte Sirai (local) 

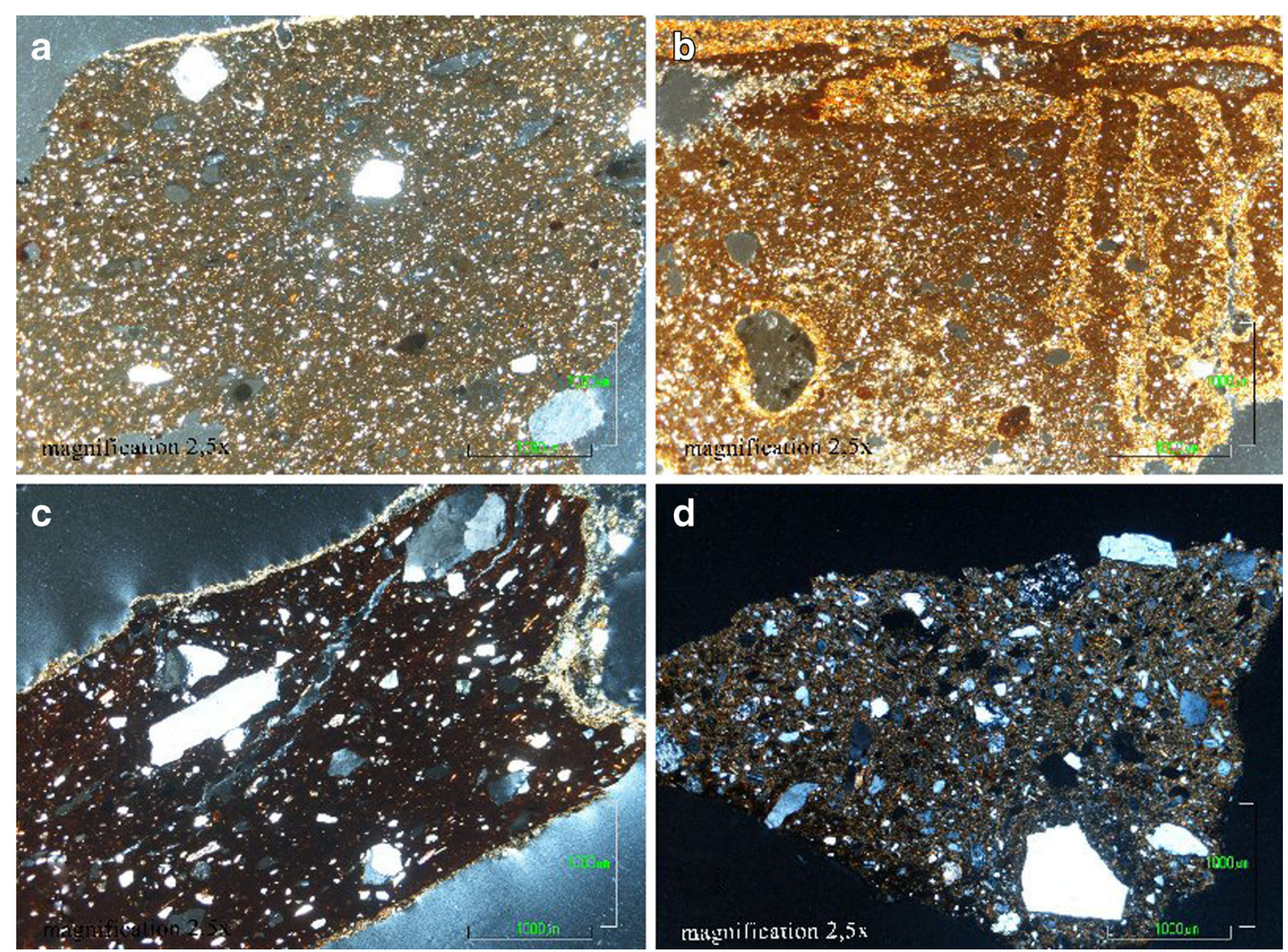

Fig. 11 a Sample SG/SS 2, transmitted light micrograph, XPL, O1 group. Jug with vertical neck, Othoca (local); b sample SG/SS 9, transmitted light micrograph, XPL, O2 group. Mushroom-lipped jug, Othoca

(local); c sample SGT 22, transmitted light micrograph, XPL, O3 group. Transport amphora T-1.4.2.1. (local); d sample SG/SS 3, transmitted light micrograph, XPL, O4 group. Transport amphora, Othoca (local)

17.39 to $19.42 \%$ ), quite high $\mathrm{K}_{2} \mathrm{O}$ (from 3.38 to $3.89 \%$ ), and medium to high $\mathrm{Fe}_{2} \mathrm{O}_{3}$ content (from 6.66 to $8.45 \%$ ).

By using simple binary correlations, the presence of these three main groups is still more evident $\left(\mathrm{CaO}-\mathrm{Al}_{2} \mathrm{O}_{3}\right.$ diagram; Fig. 12).

\section{Tharros samples}

The mineralogical and petrographic investigations allowed the identification of one main pottery group, considered local (TH1-Tharros 1), and a secondary group, represented by only
Fig. $12 \mathrm{CaO}-\mathrm{Al}_{2} \mathrm{O}_{3}$ binary correlation diagram, Othoca samples

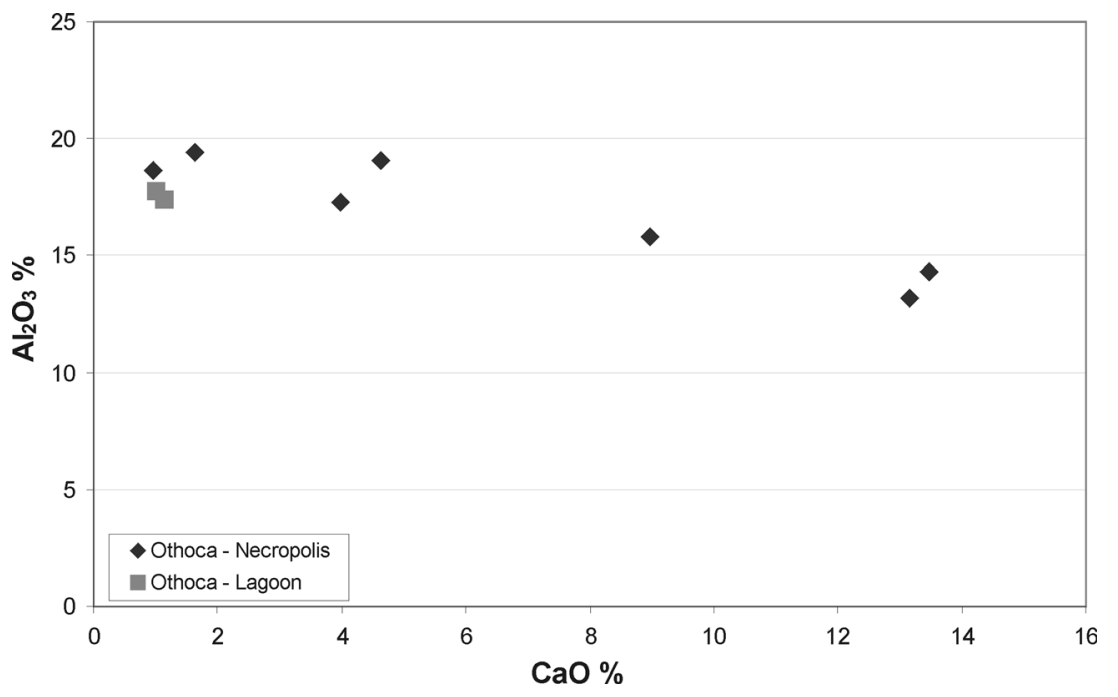



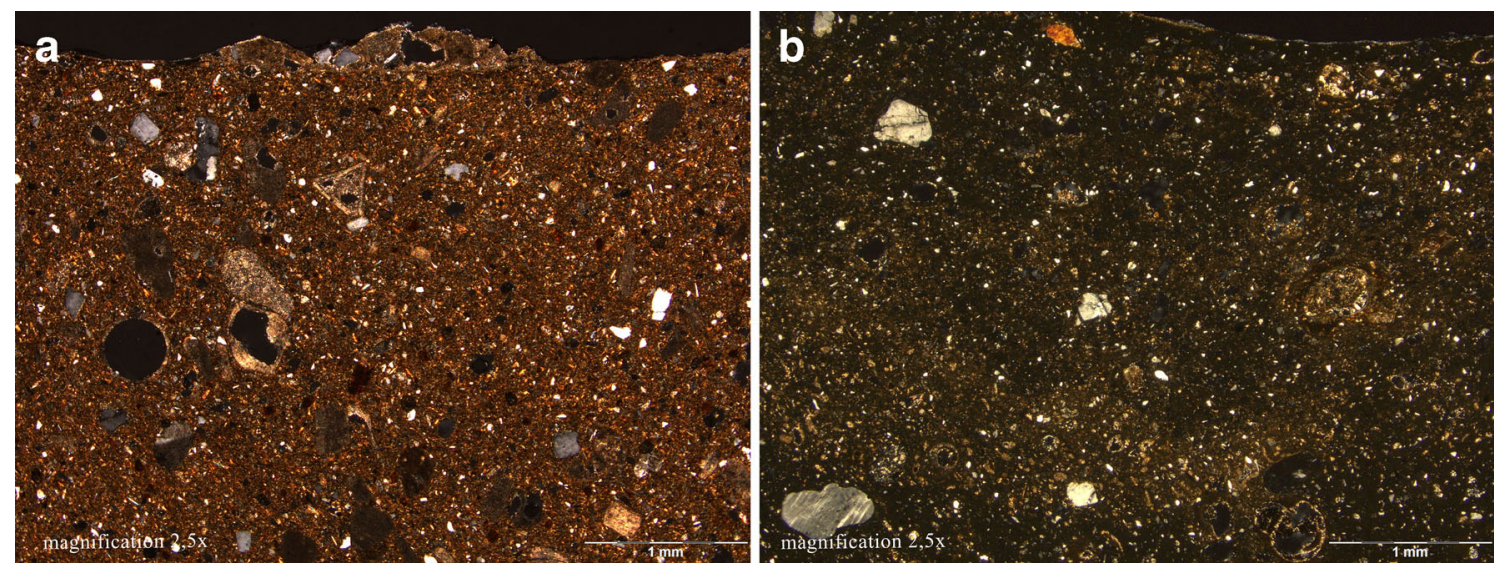

Fig. 13 a Sample THT 94/18/5-2, transmitted light micrograph, XPL, TH1 group. Plate, Tharros (local); b sample THT 94/10/10-1, transmitted light micrograph, XPL, TH2 group. Plate, Tharros (local)

two samples (TH2-Tharros 2) probably local but different than the other. The first group of ten samples shows an anisotropic matrix and a skeleton having a serial grain size distribution of aplastic with an abundant silty and very fine sandy fraction (Fig. 13a). Two samples with a semi-isotropic matrix show a hiatal grain size distribution of aplastic with silty fraction abundance (Fig. 13b). The main variable among the first ten samples is the total abundance of the skeleton, ranging from 5 to $10-15 \%$. The mineralogical composition of the aplastic fraction is rather homogeneous and mainly consists of a monocrystalline quartz, micritic and spathic carbonate rock fragments, plagioclases, mica, opaque minerals, hematite, k-feldspar, polycrystalline quartz, chert, bioclasts and rare sedimentary and metamorphic rock fragments. Fragment of volcanic rock (andesite) and pyroxene were identified in two samples too.

XRD analyses (Table 3) of TH1 group samples confirm the presence of quartz, calcite, feldspars, illite/micas and sometimes iron oxides. Traces of gehlenite were detected in five samples. In the samples of the TH2 group, few traces of calcite were detected with a large amount of quartz and feldspars; pyroxenes and gehlenite are present in all samples, together with wairakite that was probably formed during burial (Gottardi 1969).

Taking into account the firing temperatures, the situation is inhomogeneous. The constant presence of calcite (Trindade et al. 2009), the anisotropy of the matrix and the rare traces of gehlenite found in the group of ten samples allows hypothesising firing temperatures between 750 and $800{ }^{\circ} \mathrm{C}$, while the presence of pyroxenes, the scarcity of calcite and the semi-isotropy in the two samples (TH2) indicate firing temperatures around $850{ }^{\circ} \mathrm{C}$ (Trindade et al. 2009). These variations certainly indicate a different processing technology with respect to the other samples.

The chemical composition of the samples (Table 4, $\mathrm{XRF}$ data) is more or less uniform but with a certain variability in the content of $\mathrm{SiO}_{2}$ (average value of $51.42 \%$ with standard deviation of $2.47 \%$ ), $\mathrm{Al}_{2} \mathrm{O}_{3}$ (average value of $13.9 \%$ with standard deviation of $1.71 \%$ ) and $\mathrm{CaO}$ (average value of $14.82 \%$ with standard deviation of $2.84 \%)$.

The highest levels of $\mathrm{Al}_{2} \mathrm{O}_{3}$ and $\mathrm{Na}_{2} \mathrm{O}$ and the lowest content of $\mathrm{K}_{2} \mathrm{O}$ highlight the slight difference between the two samples differentiated even from the microscopic point of view and in grain size distribution from the samples belonging to the main group (TH2-Tharros 2 samples, $\mathrm{Al}_{2} \mathrm{O}_{3}-\mathrm{K}_{2} \mathrm{O}$ diagram, Fig. 14). The correlation between $\mathrm{CaO}$ and $\mathrm{LOI}$ indicates that the two TH2-Tharros 2 samples have a lower LOI content with respect to the others, due to a higher firing temperature and to the neoformation of calcium silicates (gehlenite).

\section{Pithecusa samples}

From the standpoint of mineralogical and petrographic considerations, almost all the samples show an anisotropic matrix, the skeleton abundance ranges around $10 \%$, but differ in the grain size distribution of the aplastic. Three samples (PI 2, PI 10 , PI 14) have, in fact, a hiatal grain size distribution with abundance of fine and very fine sandy fractions (Fig. 15 a), while a sample (PI 12) shows an abundance in the silty fraction (Fig. $15 \mathrm{a}, \mathrm{b}$ ). The skeleton is composed mainly of monocrystalline and polycrystalline quartz, carbonatic rocks fragments, bioclasts, rare feldspars and opaque minerals.

$\mathrm{X}$-ray diffraction analyses have evidenced a good compositional homogeneity, with abundant amounts of quartz and calcite, traces of illite/mica and feldspars; the gehlenite is present in a single sample. As regards the firing temperature, the four samples of Ischia were fired at temperatures around $750{ }^{\circ} \mathrm{C}$.

Pithecusa ceramic chemical data show a good homogeneity for most of the elements considered, as attested by a low standard deviation. The samples are characterised by a quite high and slightly variable $\mathrm{CaO}$ content (average value of $17.92 \%$ and standard deviation of $2.12 \%$ ), medium to low alumina concentrations (average value of $9.8 \%$ and standard deviation of $0.4 \%$ ), low $\mathrm{K}_{2} \mathrm{O}$ (average value of $1.31 \%$ and 
Fig. $14 \mathrm{Al}_{2} \mathrm{O}_{3}-\mathrm{K}_{2} \mathrm{O}$ binary correlation diagram, Tharros samples

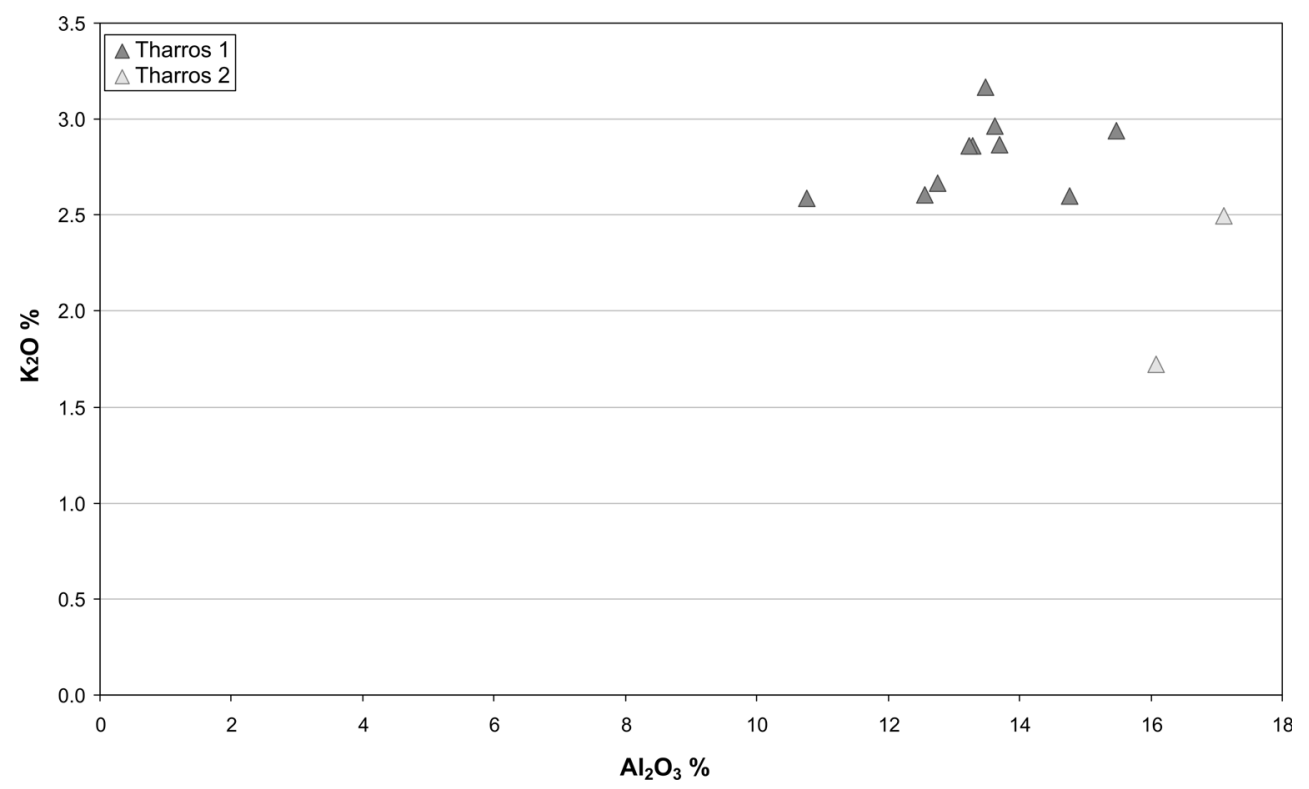

standard deviation of $0.09 \%$ ) and not particularly high iron content (average value of $4.38 \%$ and standard deviation of $0.22 \%$ ). This homogeneity suggests a common origin for all the considered samples, and the similarity with the samples coming from Carthage is evident.

\section{Raw clay materials}

Raw clay materials coming from the surroundings of Othoca (Fig. 2 a, b) were sampled and analysed to identify a possible clay source for the local ceramic production. In addition, also clayey raw materials from the Tharros area (Fig. 2 a, b) were considered (Fabbri et al. 1998). As previously reported, clays come from geological formations and outcrops present in the area, and date from Tortonian to Quaternary (Table 2).

By following the same approach used for Othoca samples, the chemical composition of the clays (XRF analyses) indicate that at least three (or four) main groups can be distinguished according to their carbonate content (Table 5).

The first group is characterized by a quite high $\mathrm{CaO}$ content (from 13.18 to $17.45 \%$ ). In this group, clays from the Tharros area, dated from Tortonian (T1 and T2) to Messinian (M2 and M6) and Quaternary (Nu1), are present. Even if some chemical differences between these samples are present, in this group, medium to low $\mathrm{Al}_{2} \mathrm{O}_{3}$ concentrations (from 9.93 to $11.42 \%$ ), medium to high $\mathrm{K}_{2} \mathrm{O}$ (from 2.21 to $2.63 \%$ ) and medium to low iron content (from 3.31 to $4.25 \%$ ) are present. This group shows some general similarities with the ceramic samples of group $\mathrm{O} 1$ from Othoca necropolis and with the ceramics of Tharros.

The second group, composed of two quaternary samples (Area 3 and Area 4), is characterised by a medium to low $\mathrm{CaO}$ content (from 4.28 to $5.0 \%$ ). These samples are similar each other and show a different chemical composition from the other Holocene clays present and sampled in the
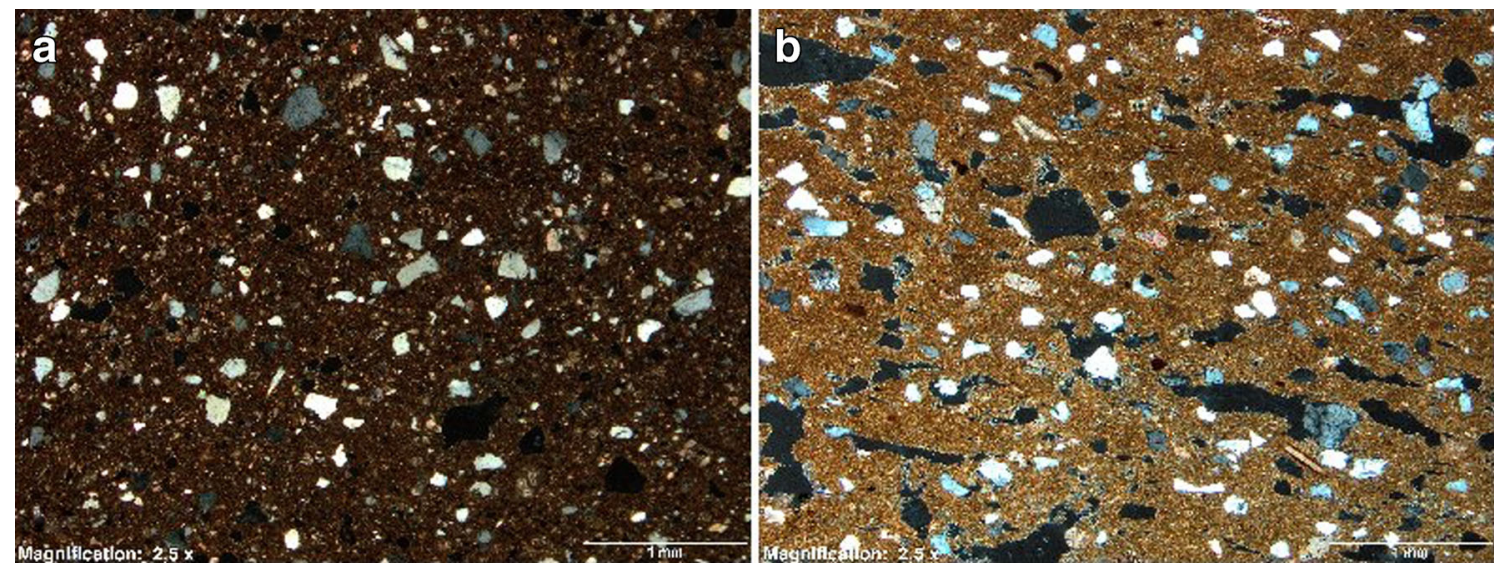

Fig. 15 a Sample PI 2, transmitted light micrograph, XPL. Pithecusa (imported); b sample PI 12, transmitted light micrograph, XPL. Pitecusa (imported) 
Table 5 Chemical composition of raw clay materials (\%)

\begin{tabular}{|c|c|c|c|c|c|c|c|c|c|c|c|c|}
\hline Sample & Location & LOI & $\mathrm{Na}_{2} \mathrm{O}$ & $\mathrm{MgO}$ & $\mathrm{Al}_{2} \mathrm{O}_{3}$ & $\mathrm{SiO}_{2}$ & $\mathrm{P}_{2} \mathrm{O}_{5}$ & $\mathrm{~K}_{2} \mathrm{O}$ & $\mathrm{CaO}$ & $\mathrm{TiO}_{2}$ & $\mathrm{MnO}$ & $\mathrm{Fe}_{2} \mathrm{O}_{3}$ \\
\hline $\mathrm{T} 1$ & Tharros & 16.18 & 2.82 & 2.02 & 10.48 & 45.38 & 0.12 & 2.42 & 16.74 & 0.56 & 0.02 & 3.26 \\
\hline $\mathrm{T} 2$ & Tharros & 16.80 & 1.97 & 1.89 & 9.93 & 47.72 & 0.12 & 2.21 & 15.51 & 0.52 & 0.03 & 3.29 \\
\hline M2 & Tharros & 15.52 & 1.42 & 2.13 & 12.03 & 46.65 & 0.12 & 2.60 & 14.61 & 0.63 & 0.03 & 4.25 \\
\hline M6 & Tharros & 17.78 & 2.37 & 1.95 & 10.78 & 43.10 & 0.12 & 2.36 & 17.45 & 0.56 & 0.03 & 3.50 \\
\hline Nul & Tharros & 14.49 & 1.35 & 1.72 & 11.42 & 51.32 & 0.12 & 2.63 & 13.18 & 0.61 & 0.02 & 3.13 \\
\hline M12 & Tharros & 8.11 & 0.91 & 2.40 & 17.14 & 58.96 & 0.34 & 2.41 & 1.65 & 0.71 & 0.05 & 7.31 \\
\hline ZA & Tharros & 9.42 & 1.81 & 2.31 & 17.18 & 51.69 & 0.85 & 1.81 & 2.14 & 0.59 & 0.23 & 11.96 \\
\hline SGT ARG & S. Giusta Lagoon & 3.17 & 1.38 & 3.98 & 17.48 & 58.49 & 0.14 & 3.12 & 1.18 & 1.10 & 0.06 & 9.90 \\
\hline US 46 & Necropolis & 5.01 & 0.91 & 3.39 & 19.88 & 57.03 & 0.12 & 4.13 & 1.49 & 0.98 & 0.06 & 6.99 \\
\hline AREA 1 & Othoca & 8.57 & 1.21 & 2.75 & 17.66 & 58.04 & 0.16 & 3.55 & 1.31 & 0.81 & 0.05 & 5.88 \\
\hline AREA 2 & Othoca & 10.05 & 1.17 & 2.38 & 18.06 & 56.90 & 0.08 & 3.47 & 1.06 & 0.78 & 0.07 & 5.97 \\
\hline AREA 3 & Othoca & 4.89 & 1.57 & 1.60 & 12.87 & 66.11 & 0.89 & 3.35 & 5.00 & 0.49 & 0.06 & 3.16 \\
\hline AREA 4 & Othoca & 7.46 & 1.66 & 1.72 & 12.99 & 63.87 & 0.98 & 3.16 & 4.28 & 0.49 & 0.05 & 3.36 \\
\hline AREA 5 & Othoca & 9.51 & 1.18 & 2.26 & 17.51 & 56.65 & 0.35 & 3.85 & 1.82 & 0.73 & 0.07 & 6.08 \\
\hline
\end{tabular}

immediate surroundings, suggesting a different genesis. They differ mainly for a different content in $\mathrm{MgO}, \mathrm{P}_{2} \mathrm{O}_{5}, \mathrm{SiO}_{2}$, $\mathrm{Al}_{2} \mathrm{O}_{3}$ and $\mathrm{TiO}_{2}$, oxides that can be linked to the detrital fraction, as previously hypothesised. Some samples from Othoca necropolis (group $\mathrm{O} 4$ ) have a similar $\mathrm{CaO}$ content, but they differ in the concentrations of nearly all the other oxides ( $\mathrm{MgO}, \mathrm{P}_{2} \mathrm{O}_{5}, \mathrm{SiO}_{2}, \mathrm{Al}_{2} \mathrm{O}_{3}, \mathrm{TiO}_{2}$ and $\mathrm{Fe}_{2} \mathrm{O}_{3}$ ).

The third group is characterized by clays with a low $\mathrm{CaO}$ content (from 1.18 to $1.82 \%$ ). This group is composed only by Quaternary clays from the Tharros area (M12) and from the Othoca area and the Lagoon. Even if some chemical differences between these samples are present, in this group, medium to high $\mathrm{Al}_{2} \mathrm{O}_{3}$ concentrations (from 17.14 to $19.88 \%$ ), $\mathrm{K}_{2} \mathrm{O}$ (from 2.40 to $4.13 \%$ ) and $\mathrm{Fe}_{2} \mathrm{O}_{3}$ content (from 5.97 to $9.9 \%$ ) are present. This group shows some general similarities with the ceramic samples of groups $\mathrm{O} 2$ and $\mathrm{O} 3$ from Othoca necropolis and from the Lagoon.

Finally, one Pliocene sample from the Tharros area (ZA) differs in composition from the others considered. The $\mathrm{CaO}$ content $(2.14 \%)$ is slightly higher than that in the previous group, and the $\mathrm{Fe}_{2} \mathrm{O}_{3}$ content $(11.9 \%)$ is definitively higher with respect to the other groups. None of the ceramic samples analysed for this area have a comparable amount of iron.

A more detailed comparison between the chemical data of the raw clay materials and the ceramic samples from the several sites considered will be made in the following section (the "Discussion" section), by using both binary correlations, PCA and cluster analysis.

\section{Discussion}

In the evaluation of the data, binary correlations have been made to verify firstly if the differences obtained either by optical microscopy and by a preliminary examination of the chemical data had a diagnostic significance too.

In the global binary correlation diagrams (Figs. 16-18), Carthage samples are located in a different area from most of the other samples and this allowed a first immediate distinction for the Carthage ceramics. As for Toscanos (Figs. 1618), the presence of two clearly distinct groupings is evident. The Toscanos-T2 group fits with the Carthage-C2 group (Fig. 19). This is also confirmed by the PCA analysis (Fig. 20) in which six samples of the Toscanos-T2 group fit with the pottery from Carthage.

Cluster analysis was performed on two separate datasets to better prove the similarity within the two sub-groups: the first one (Fig. 21) formed by not local pottery (namely Carthage and importation samples from Carthage from the colonies of Pithecusa, Toscanos and Sulci) and the second one (Fig. 22) represented by the ceramic samples from Sardinia (namely Othoca, Tharros, Monte Sirai and Sulci).

In the cluster dendrogram of imported pottery (Fig. 21), the samples from Carthage belonging to the two groups $\mathrm{C} 1$ and C2 (see Table 3) have been highlighted; samples CA 757 and CA 605 (identified as isolated in Table 3) match with the samples belonging to the C2 group, while samples CA 297 and CA 295 (identified as isolated too) match with the samples belonging to the $\mathrm{C} 1$ group.

In the correlation diagrams (Figs. 16-18), the presence of two clearly distinct clustering of Sulci samples is evident; the samples of the S2 group fit with the Carthage C2 group (Fig. 19). The presence of these two groups has been confirmed by PCA (Fig. 20) and cluster analysis (Fig. 21).

In the correlation diagrams (Figs. 16-18), Monte Sirai samples are positioned in a different area than the Carthage group. The Monte Sirai samples show a general chemical affinity with the local group (S1) of Sulci samples, from which they 


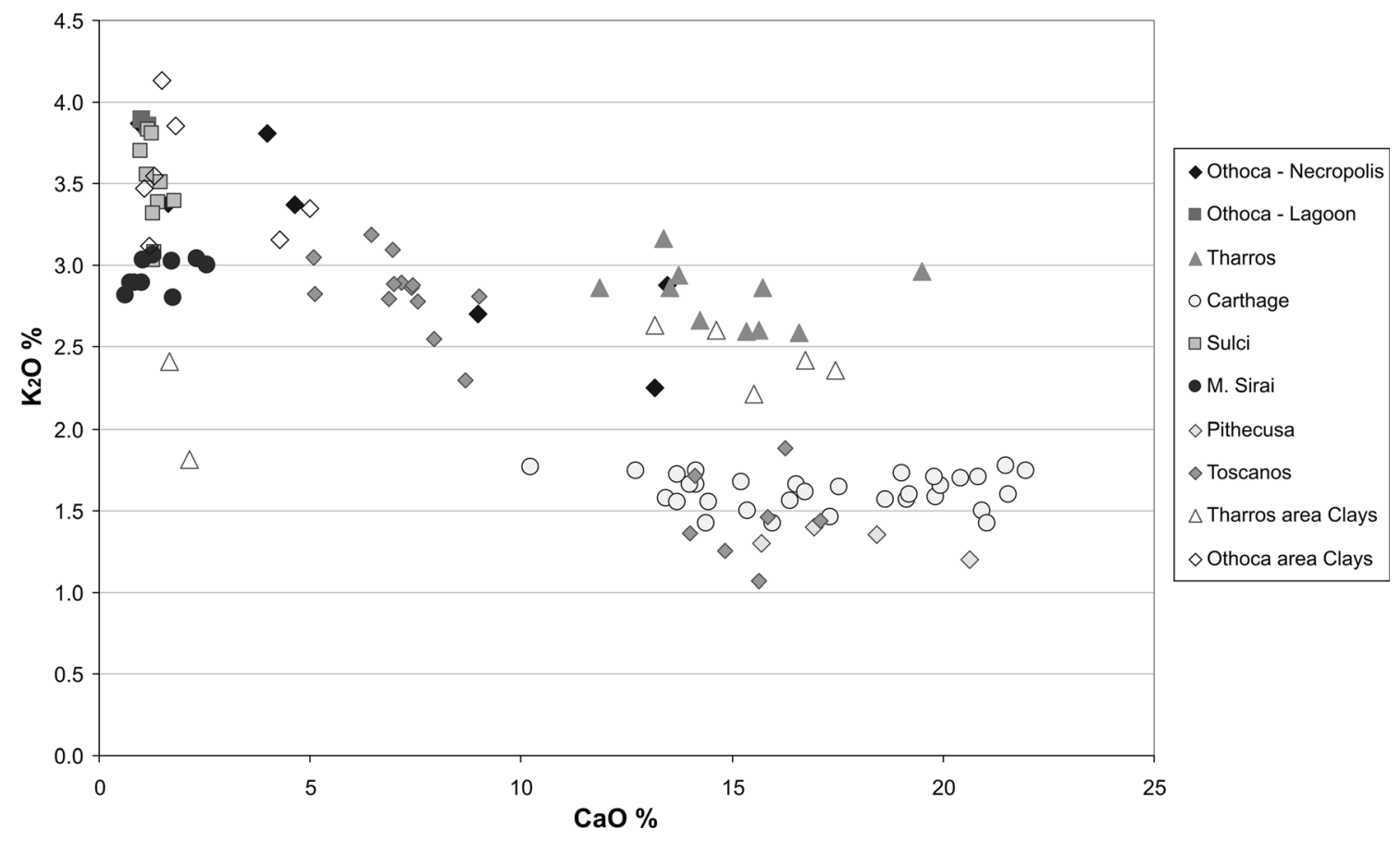

Fig. $16 \mathrm{CaO}-\mathrm{K}_{2} \mathrm{O}$ binary correlation diagram for all ceramic and clay samples

mainly differ in the $\mathrm{K}_{2} \mathrm{O}$ content. This affinity is confirmed by PCA (Fig. 20) and cluster analysis (Fig. 22).

In the binary correlation diagrams of Fig. 16, the ceramic samples from Othoca (necropolis and Lagoon) are widespread, but they are systematically positioned in a different area than Carthage ceramics. As previously reported, $\mathrm{CaO}$ content (Fig. 16, Table 4) varies from a minimum of 0.95 $1.63 \%$ (groups $\mathrm{O} 2$ and $\mathrm{O} 3$ from the Lagoon and the necropolis) to a maximum of $13.46 \%$ (group $\mathrm{O} 1$ from the necropolis). With regard to the raw materials, the clay samples from the Lagoon and few samples from Othoca necropolis have a corresponding $\mathrm{CaO}$ content. None of the clays from the Othoca area have a $\mathrm{CaO}$ content compatible with carbonatic ceramic samples. Since the use of a carbonatic filler in the aggregate or in the matrix is not evident from optical microscopy observations, different raw sources than Othoca

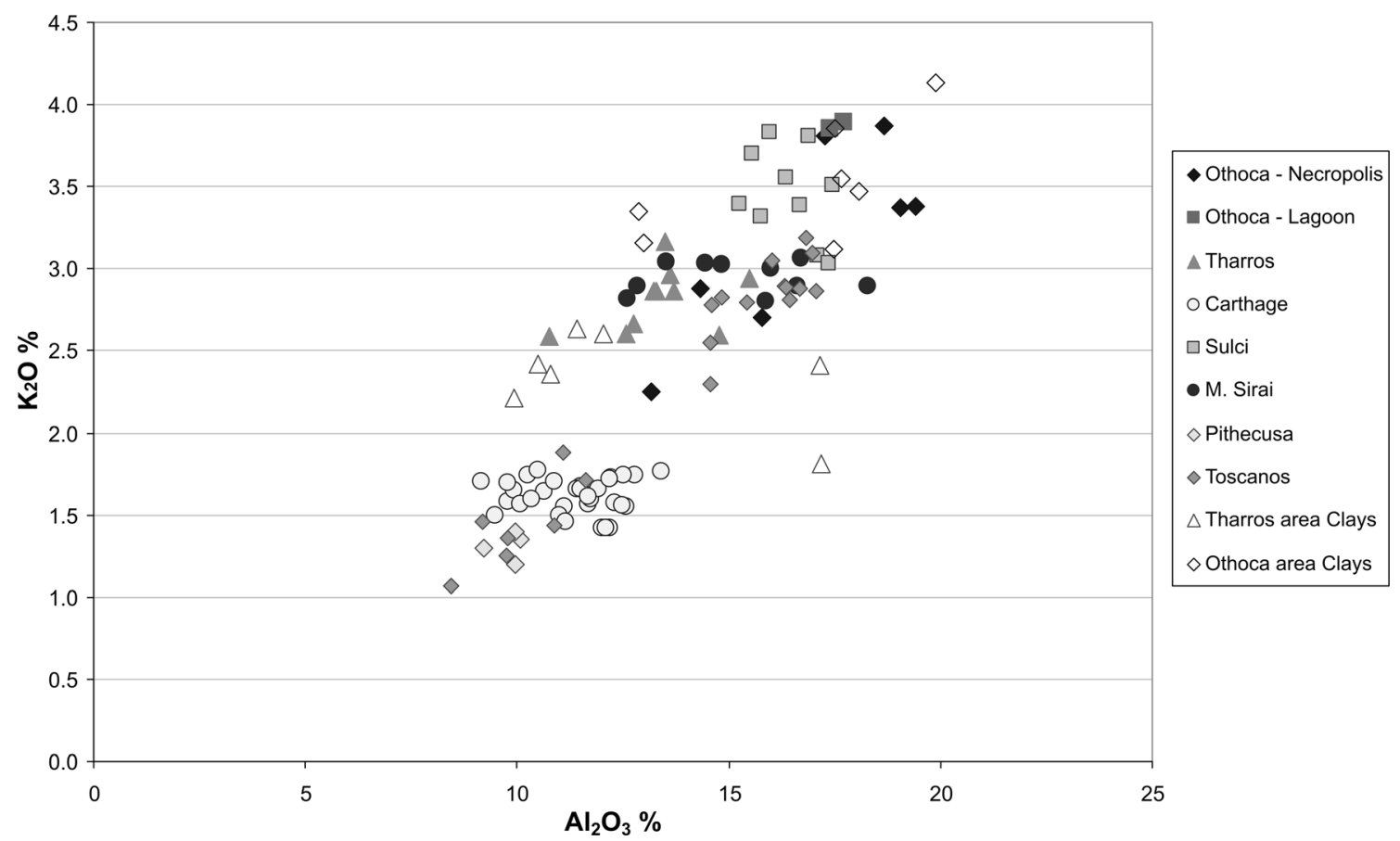

Fig. $17 \mathrm{Al}_{2} \mathrm{O}_{3}-\mathrm{K}_{2} \mathrm{O}$ binary correlation diagram for all ceramic and clay samples 


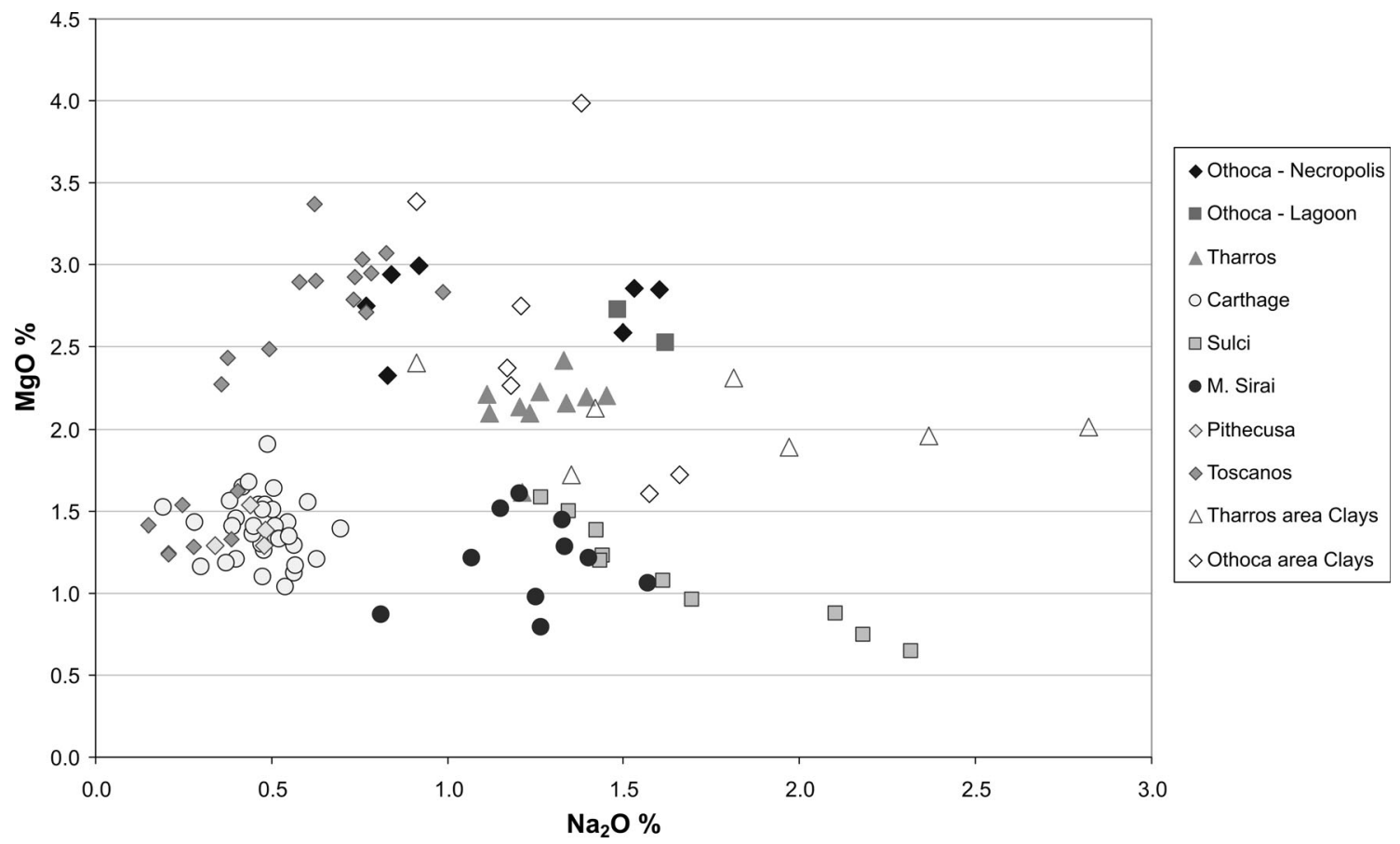

Fig. $18 \mathrm{Na}_{2} \mathrm{O}-\mathrm{MgO}$ binary correlation diagram for all ceramic and clay samples

clays must be hypothesised for these samples. According to the considered elements, the most carbonatic samples from the necropolis show a better affinity with the raw materials from the Tharros area (Miocene or Quaternary clays). As far as the other chemical elements are concerned, the carbonatic samples show lower contents in $\mathrm{K}_{2} \mathrm{O}, \mathrm{SiO}_{2} \mathrm{Fe}_{2} \mathrm{O}_{3}$ and other major elements, as a consequence of the higher $\mathrm{CaO}$ content.
In Figs. 16 and $17\left(\mathrm{CaO}-\mathrm{K}_{2} \mathrm{O}\right.$ and $\mathrm{Al}_{2} \mathrm{O}_{3}-\mathrm{K}_{2} \mathrm{O}$ diagrams), a different $\mathrm{K}_{2} \mathrm{O}$ content in the carbonatic samples with respect to the other samples was detected. In Fig. $18\left(\mathrm{Na}_{2} \mathrm{O}-\mathrm{MgO}\right.$ diagram), the three carbonatic samples fit together, as well as the non-carbonatic ones. This diagram suggests a common origin for the three main groups of Othoca ceramics and a local raw material provenance.

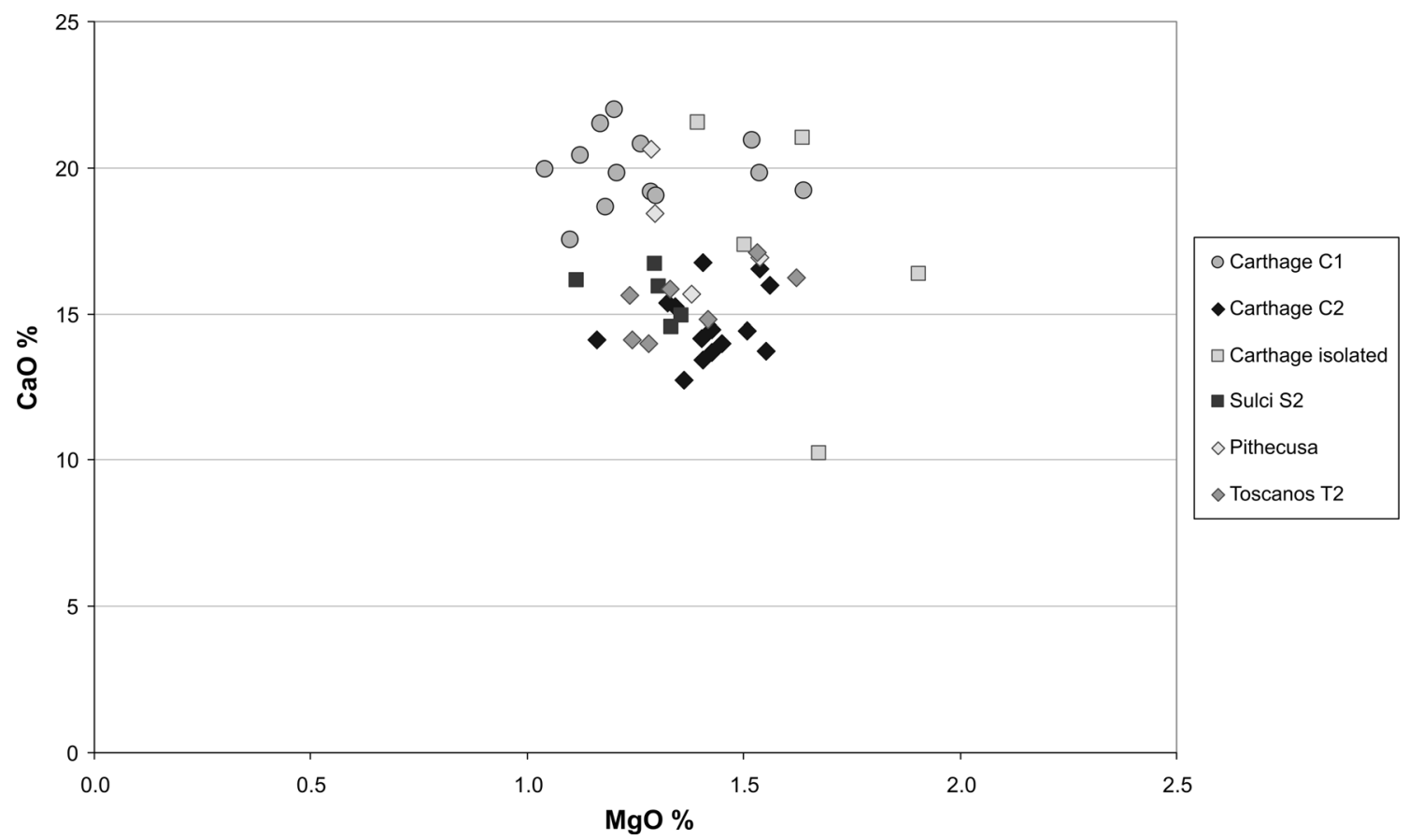

Fig. $19 \mathrm{MgO}-\mathrm{CaO}$ binary correlation diagram. Carthage, Sulci, Pithecusa and Toscanos-T2 samples 
Fig. 20 Principal component analysis among local and imported pottery and clay samples carried out on the element determined by XRF analysis; the loading plot is also reported on the bottom of the figure
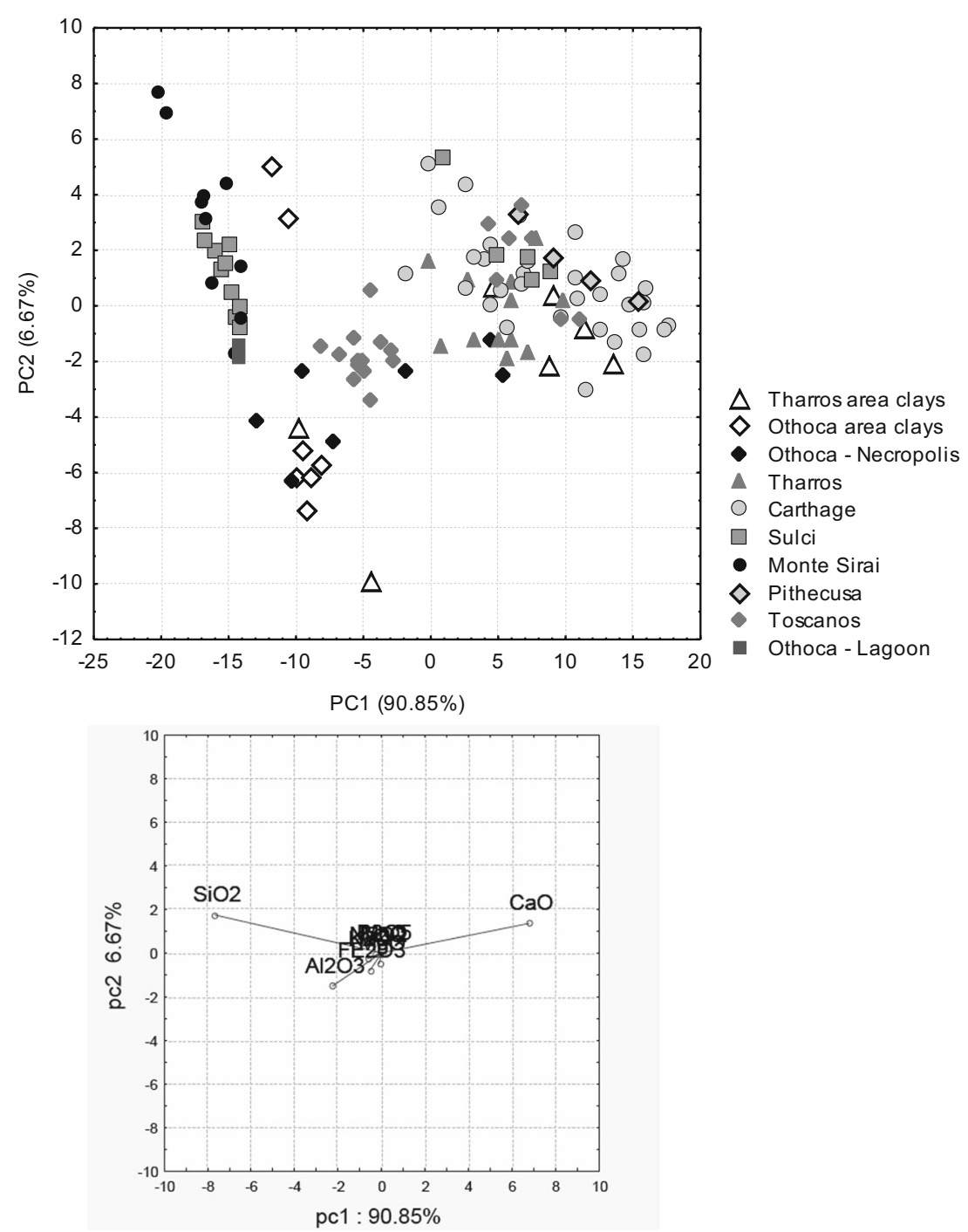

The weak chemical affinity sometimes shown for the midcarbonatic Othoca samples with Toscanos samples can be excluded on the base of the mineralogical and petrographic observations because there are no similarities between Toscanos and Othoca ceramics.

The splitting of the Othoca samples into several groups characterised by different chemical characteristics is confirmed by either PCA and cluster analysis (Figs. 20 and 22).

In the binary correlation diagrams, which include all the data (Figs. 16-18), Tharros samples are widespread, but they are placed systematically in an area different from the one of Carthage groupings. A slight affinity with some samples from the Othoca necropolis is sometimes present even if not systematic. The two high-temperature ceramic samples of the TH-2 group fall often outside the main cluster of Tharros samples, since they are characterised by the highest levels of $\mathrm{Al}_{2} \mathrm{O}_{3}$ and $\mathrm{Na}_{2} \mathrm{O}$, and the lowest content of $\mathrm{K}_{2} \mathrm{O}$. On the basis of the cluster analysis (Fig. 22), these samples are highly homogeneous and clearly distinct from the other Sardinia productions, suggesting a common and local origin.

In the binary correlation diagrams (Figs. 16-18), the Pithecusa ceramic samples show a good homogeneity for most of the elements considered and always fit together with the ones from Carthage, as confirmed also by the PCA analysis (Fig. 21). In the correlation diagram of Fig. 19, two Pithecusa samples fit with the Carthage $\mathrm{C} 1$ group and the other two with the Carthage C2 group, suggesting a more complex situation with respect to the other Phoenician colonies considered. This situation has been confirmed also by the results of cluster analysis (Fig. 21).

Considering all the complete dataset, it is evident that the correlation diagrams reported in Figs. 16-18 show a wide diagnostic capability in order to define the provenance areas both of the local and the importation of Archaic Phoenician and Punic pottery considered in this work. In these diagrams, the ceramics from Carthage always fit together in an area 
Fig. 21 Cluster dendrogram of imported pottery; the samples from Carthage and belonging to the two groups $\mathrm{C} 1$ and $\mathrm{C} 2$ have been highlighted; samples belonging to $\mathrm{C} 1$ are indicated with degree while samples belonging to $\mathrm{C} 2$ are indicated with asterisk

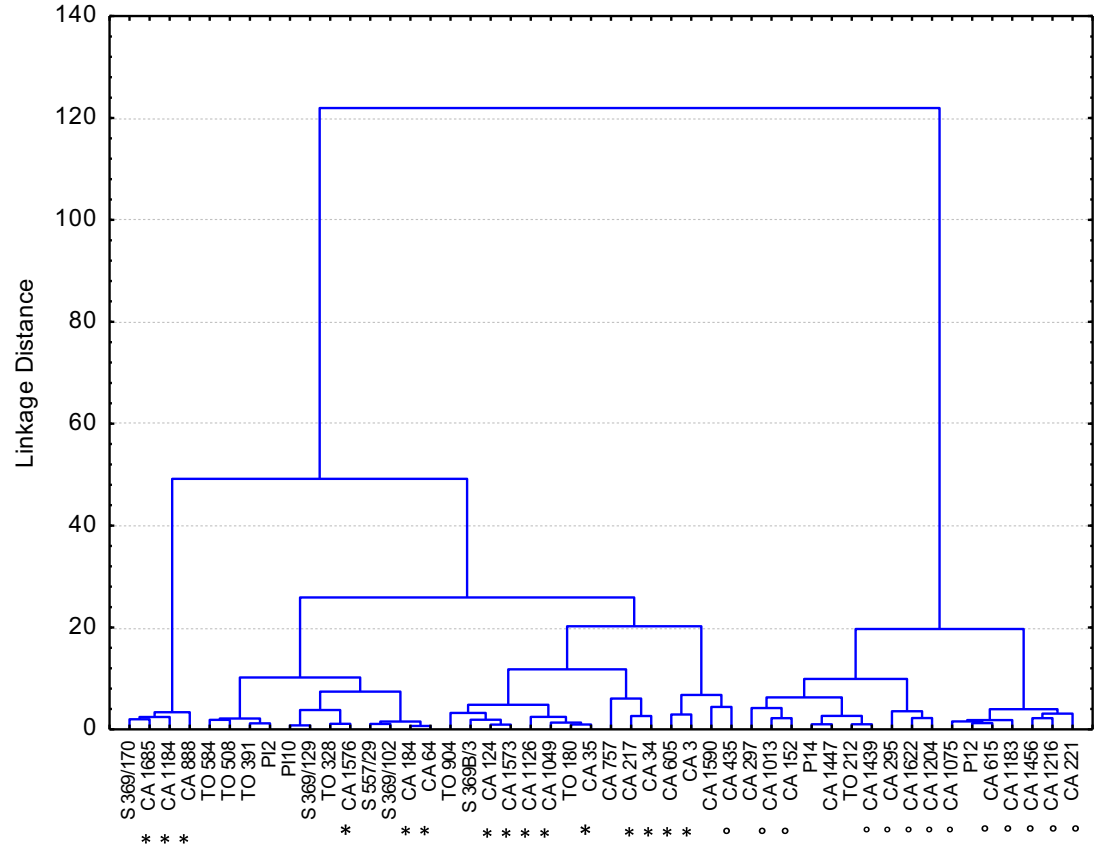

where no local pottery or clays are present. This allows with a good degree of reliability to determine a provenance from Carthage for unknown pottery on the basis of the chemical data only. One sample from Tharros is overlapped to the Carthage pottery samples in the first correlation diagram (Fig. 16). This uncertainty can be solved with the aim of the other diagrams (Figs. 17 and 18), where this overlapping is not present.

In the diagram of Fig. $16\left(\mathrm{CaO}-\mathrm{K}_{2} \mathrm{O}\right)$, four main groupings are present: (i) Carthage ceramics and importation ceramics from Carthage; (ii) a group formed by carbonatic local ceramics from Tharros and Othoca necropolis, overlapped to Miocene and Quaternary clay samples from the Tharros area; (iii) slightly carbonatic ceramics from Toscanos and from Othoca necropolis and two clay samples from the Othoca area; (iv) non-carbonatic ceramics from Sulci, Monte Sirai, Othoca necropolis and Othoca Lagoon and clay samples from the Othoca area.

If we take into account $\mathrm{Al}_{2} \mathrm{O}_{3}-\mathrm{K}_{2} \mathrm{O} \mathrm{MgO}-\mathrm{CaO}$ diagrams (Figs. 17 and 18), these groupings, with major or minor overlapping, are present as well. The $\mathrm{Al}_{2} \mathrm{O}_{3}-\mathrm{K}_{2} \mathrm{O}$ diagram (Fig. 17) allows good discrimination between the Carthaginians and other Phoenician pottery considered. The $\mathrm{K}_{2} \mathrm{O}$ content in the Carthaginian samples is always lower than that in the local ones, with a remarkable homogeneity of the data. Other Phoenician ceramics are not so homogeneous and the $\mathrm{K}_{2} \mathrm{O}$ content (with the only exception of one sample from Tharros and one from the Pliocene clays in the Tharros area) spread from 2.2 to more than $4 \%$. The $\mathrm{Na}_{2} \mathrm{O}-\mathrm{MgO}$ correlation diagram (Fig. 16) shows as well the four groupings, with some minor overlapping.

In Sulci and Toscanos pottery, two different groups of ceramics are distinguishable because of the lower calcium oxide content and significant higher aluminium oxide content; one of them has a local provenance (S1 and T1) while the other is imported (S2 and T2) as indicated before.

All the correlations considered showed a good affinity between Sulci and Monte Sirai samples, where only some minor differences are present. This can suggest that, probably, the source of raw clay materials could be similar, at least from the geological point of view.

Local Toscanos ceramics are chemically different from the others, and this reflects the different compositions observed both by microscopic in thin section and by XRD analyses.

Tharros samples overlap to the group formed by raw clay materials (Miocene to Quaternary clays) coming from the surroundings of the settlement. Since the compositional spread of these samples is wide, it is not possible to define which kind of clay have been used without a statistical treatment of the data.

The Othoca samples show the widest spread in all the correlation diagrams considered. As far as the raw clay materials are considered, some of the ceramic samples (non-carbonatic, groups O2-O3) show an affinity with the Othoca clays, whilst this does not happen for the carbonatic samples. Since both the local ceramic and the raw materials show a wide spread of the data and some overlapping too, for these samples, a provenance determination on the base of a simple binary correlation is not always possible.

A quite relevant group of samples is always completely overlapped to the cluster formed by Carthaginian pottery. All these samples (from Pithecusa and some of Sulci and Toscanos) constitute a ceramic importation from Carthage. In the samples from Othoca, Tharros and Monte Sirai, no coeval importations from Carthage were observed.

In the statistical treatment of the data, by means of classification methods, some homogeneous groups within the 
Fig. 22 Cluster dendrogram of local pottery; the following symbols have been used to indicate the groups: asterisk for $\mathrm{S} 1$, degree for MS, section sign for $\mathrm{SG}$, positive sign for $\mathrm{TH}$

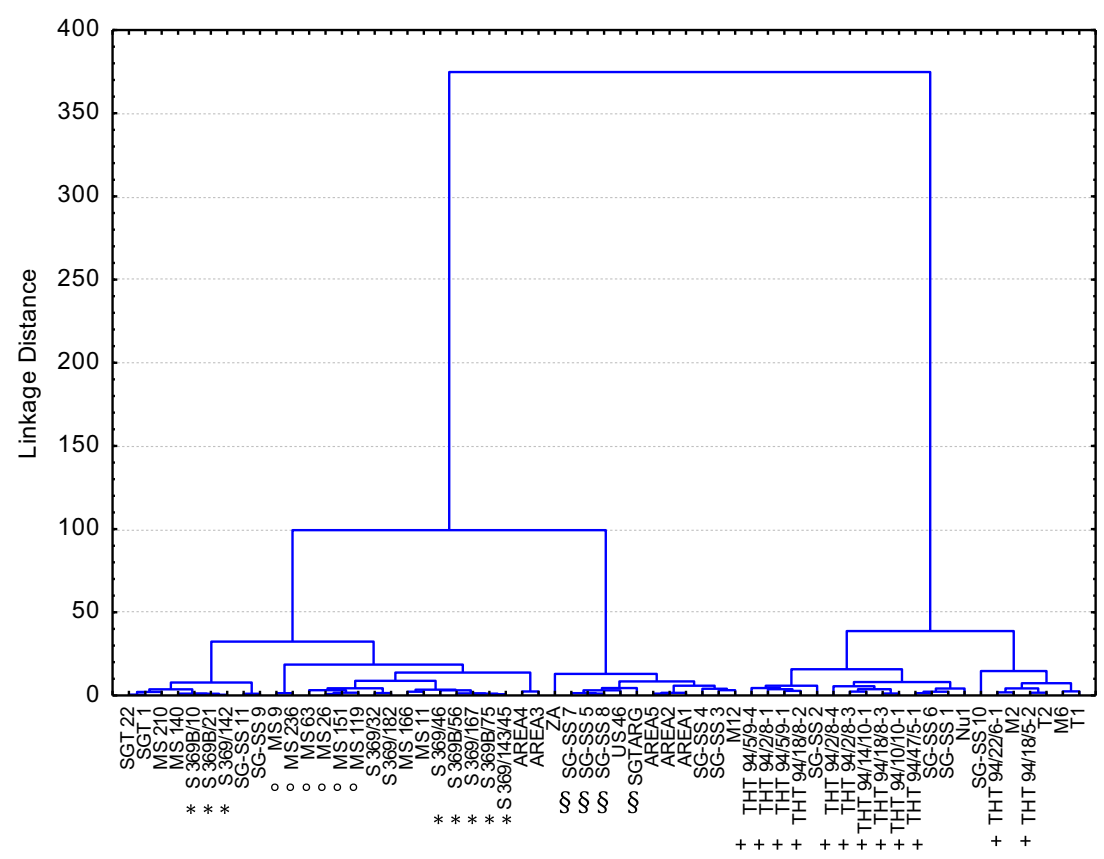

different productions have been identified. The presence of some distinct groups is evident from PCA (Fig. 21). It is worth noting that the variance explained by the first two components is very high (99.5\%). From the score plot reported in Fig. 21, the presence of a group formed by the Othoca-S. Giusta Lagoon, Sulci and Monte Sirai samples is evident.

Furthermore, the composition of Othoca necropolis samples is compatible with the local clays from the same area. A more complex situation is observable for all the other Othoca samples.

As regards the imported ceramics (Fig. 21), two groups are present: one formed by Toscanos (T2), Sulci (S2), two samples from Pithecusa and $\mathrm{C} 2$ pottery sample from Carthage, the other with $\mathrm{C} 1$ pottery sample from Carthage and two samples from Pithecusa. This differentiation into two groups (with a high linkage distance) better details the indications obtained by the $\mathrm{MgO}-\mathrm{CaO}$ correlation diagram (Fig. 19) and confirms the archaeological hypothesis.

Concerning local pottery (Fig. 22), it was possible to highlight a first group consisting of samples from Sulci, Monte Sirai and Othoca-S. Giusta Lagoon in accordance with the PCA results; Othoca necropolis and the clays from the same area show a high similarity (low linkage distance); Tharros samples (TH1 and TH2) form a separate group and fit with some local clays from the same area.

Within the Tharros group, most of the samples together with three Othoca ceramic samples fit with the Quaternary clay sample (Nu1), whilst only two Tharros samples together with one sample from the Othoca necropolis show an affinity with Miocene clays (Tortonian and Messinian). This different behaviour suggests that more than one clay source (Quaternary and Miocene formations) could have been used to realise the local pottery from Tharros and maybe some of the Othoca necropolis one (i.e. the carbonatic samples).

The cluster indicates that most samples from Sulci and Monte Sirai fit together too, suggesting a similar origin for these ceramics. Within the Monte Sirai-Sulci cluster, two raw clay samples are present too (Area 3 and Area 4), indicating that no affinity with local pottery from Othoca is present for these clays.

Most of the samples from the Othoca necropolis fit together close to some raw clay samples (Area 1, Area 2, Area 5, US 46 and the Quaternary M12 clay), indicating as a possible source for these ceramics the local Quaternary clays present in the Othoca area.

Finally, a group of four ceramics (two from Othoca necropolis and two from the S. Giusta Lagoon) falls apart together with some Sulci and Monte Sirai samples, indicating that a different source is present too whose raw materials have not yet been identified.

\section{Conclusions}

The archaeometric researches carried out on Phoenician and Punic pottery in order to find features related to the different ceramic productions and their provenance highlighted a very complex situation. In the analysed samples several ceramic groupings can be considered from the mineralogical, petrographic and chemical point of view, mainly according to their calcium carbonate content.

The use of homogeneous data has allowed the definition of a first chemical database that could represent the starting point 
for a reliable classification method to discriminate in between Archaic Phoenician and Punic pottery firstly on the basis of their chemical composition.

The results suggest that importation of pottery from Carthage is present in several Phoenician Archaic settlements, in particular in Toscanos, Sulci as well as Pithecusa. In the sample analysed from Othoca, Tharros and Monte Sirai, no importations from Carthage are present. The division into two main groups for the Carthage samples and for Toscanos samples was confirmed by statistical processing of data.

PCA has confirmed the reliability of the database, attesting the presence of importation ceramics. A first cluster analysis has confirmed the existence of two main groups in the Carthage ceramics, the same for imported ceramics from Carthage in the other settlements, as previously suggested by chemical binary correlations. The second cluster analysis has allowed a grouping between local pottery from Sardinia, suggesting the possible affinity with the local raw clay materials considered. This cluster allowed the division into four main sub-groups. The first group indicates that more than one raw clay source (probably Quaternary and Miocene geological formations) could have been used to realise the local ceramic from Tharros and probably also the ceramic from Othoca necropolis. In the second group. most of the samples from Sulci and Monte Sirai fit together, suggesting a similar origin for these ceramics. In the third group, most of the samples from Othoca necropolis fit together close to some raw clay samples, indicating as a possible source for these ceramics the local Quaternary clays present in the Othoca area. Finally, a group of four ceramics (two from Othoca necropolis and two from the Lagoon) falls apart together with some Sulci and Monte Sirai samples, indicating that a different source is also present whose raw clay materials have not yet been identified.

The obtained results will allow the use of the reference database to distinguish the ceramics imported from Carthage and the local Phoenician Archaic pottery productions.

From the historical point of view, these results confirm, as expected, that the majority of the ceramics analysed was local, compared to a poor attestation of import materials, mainly of Carthaginian production (Peserico 1998, 2000). The presence of pottery produced in Carthage in Toscanos, Sulci and Pithecusa allowed drawing of historical conclusions in relation to contacts between Carthage and the other Mediterranean sites since the Archaic period. Morphological analysis allowed verification of the uniformity of the repertoire of the forms of oriental tradition, both in Carthage and in other western colonies, and the early appearance of western forms with regional morphological variants, in some cases with reciprocal influences between the different colonial areas. The early presence of Carthaginian pottery in Sardinia, linked to the possible presence on site of African residents, had led to the hypothesis that the morphological evolution of the forms of western origin could have been influenced by Carthage, while in the Iberian area this influence was felt later and with limited and discontinuous outcomes (Peserico 1998, 2000).

The analysis performed on Othoca samples did not allow instead the identification of materials imported from Carthage; this is likely due to the failure to identify, in the necropolis and in the Lagoon, the materials attributable to the eighth and first half of the seventh centuries BC. We have verified the absolute predominance of pottery probably produced locally and the presence of some samples of unidentified origin opens new possibilities of local or Mediterranean exchanges that has yet to be fully investigated. So, we also have the confirmation of the economic dynamism of the city, which was probably the seat of a substantial production of transport amphorae related to specialised agricultural crops grown in the hinterland, such as the vine and fruit trees, and of a large-scale breeding mainly related to sheep and goats (Del Vais and Sanna 2012).

\section{References}

Amadori M, Amadori ML, Fabbri B (1996) Indagini sulle materie prime locali adatte per la produzione della ceramica punica di Tharros. Riv Stud Fenici XIV:147-155

Amadori ML, Fabbri B (1998a) Indagini archeometriche su ceramica fenicia da mensa proveniente da Cartagine (VIII-VI secolo a. C.). In: Acquaro E, Fabbri B (eds) Produzione e circolazione della ceramica fenicia e punica nel Mediterraneo: il contributo delle analisi archeometriche. Atti della $2^{\mathrm{a}}$ Giornata di Archeometria della Ceramica (Ravenna, 14 maggio 1998). University Press Bologna, Imola, pp. 43-55

Amadori ML, Fabbri B (1998b) Studio archeometrico di ceramica fenicia (VIII - VI secolo a.C.) proveniente da siti archeologici della Sardegna e Ischia. In: Acquaro E, Fabbri B (eds) Produzione e circolazione della ceramica fenicia e punica nel Mediterraneo: il contributo delle analisi archeometriche. Atti della $2^{\text {a }}$ Giornata di Archeometria della Ceramica (Ravenna, 14 maggio 1998). University Press Bologna, Imola, pp. 68-84

Amadori ML, Fabbri B (1998c) Produzione locale e importazioni di ceramiche fenicie da mensa (fine VIII-fine VII secolo a.C.) a Toscanos (Spagna meridionale). In: Acquaro E, Fabbri B (eds) Produzione e circolazione della ceramica fenicia e punica nel Mediterraneo: il contributo delle analisi archeometriche. Atti della $2^{\mathrm{a}}$ Giornata di Archeometria della Ceramica (Ravenna, 14 maggio 1998). University Press Bologna, Imola, pp. 85-94

Aubet ME (2009) Tiro y las colonias fenicias de Occidente. Tercera edición actualizada y ampliada. Crítica, Barcelona

Baxter MJ (1994) Exploratory multivariate analysis in archaeology. Edinburg University Press, Edinburg

Baxter MJ, Buck CE (2000) Data handling and statistical analysis. In: Ciliberto E, Spot E (eds) Modern analytical methods in art and archaeology. Chemical Analysis Series, vol 155. Wiley, New York, pp. 681-742

Carmignani L (1996) Carta geologica della Sardegna (Foglio Sud). A cura del Servizio Geologico Nazionale e della Regione Autonoma della Sardegna 
Cultrone G, Rodriguez-Navarro C, Sebastian E, Cavalla O, De La Torre MJ (2001) Carbonate and silicate phase reactions during ceramic firing. Eur J Mineral 13:621-634

Del Vais C (2010) L'abitato fenicio-punico e romano. In: Coroneo R (ed) La Cattedrale di Santa Giusta. Architettura e arredi dall'XI al XIX secolo. Scuola sarda Editrice, Cagliari, pp. 35-46

Del Vais C, Sanna I (2012) Nuove ricerche subacquee nella laguna di Santa Giusta (OR) (campagna del 2009-2010). In: Arru MG, Campus S, Cicilloni R, Ladogana R (eds) Ricerca e confronti 2010. Atti. Giornate di studio di archeologia e storia dell'arte a 20 anni dall'istituzione del Dipartimento di Scienze Archeologiche e Storico-artistiche dell'Università degli Studi di Cagliari (Cagliari, 1-5 marzo 2010). ArcheoArte. Rivista elettronica di Archeologia e Arte, suppl. 1: 201-233 [http://ojs.unica.it/index.php/archeoarte/article/view/595]

Docter R (2000) Pottery, graves and ritual I: Phoenicians of the first generation in Pithekoussai. In: Bartoloni P, Campanella L (eds) La ceramica fenicia di Sardegna. Dati problematiche e confronti. Atti del primo Congresso Internazionale Sulcitano (Sant'Antioco, 19-21 Settembre 1997). Collezione di Studi Fenici, vol 40. Consiglio Nazionale delle Ricerche, Roma, pp. 135-149

Emami SM, Trettin R (2010) Phase generating processes in ancient ceramic matrices through microstructure investigation with high resolution microscopy methods. J Adv Microsc Res 5(3):181-189

Fabbri B, Amadori M, Amadori ML (1998) Local and imported Punic pottery (IV-III century B.C.) from Tharros (western Sardinia, Italy). Rev Archéometrie 22:65-76

Fermo P, Cariati F, Ballabio D, Consonni V, Bagnasco G (2004) Classification of ancient Etruscan ceramics using statistical multivariate analysis of data. App Phys A 79:299-307

Fermo P, Delnevo E, Lasagni M, Polla S, de Vos M (2008) Application of chemical and chemometric analytical techniques to the study of ancient ceramics from Dougga (Tunisia). Microchem J 88:150-159

Gottardi G (1969) The genesis of zeolites. Eur J Mineral 1:479-487

Heimann RB, Maggetti M (1981) Experiments on simulated burial of calcareous Terra Sigillata (mineralogical change). Preliminary results. In: Hughes MJ (ed) Scientific studies in ancient ceramics. British Museum Occasional Paper, 19, London, pp 163-177
Niemeyer HG et al. (2007) Karthago. Die Ergebnisse der Hamburger Grabung unter dem Decumanus Maximus. Hamburger Forschungen zur Archäologie, 2. Verlag Philipp von Zabern, Mainz am Rhein

Noll W (1991) Alte Keramiken und ihre Pigmente: Studien zu Material und Technologie, E. Schweizerbart, Stuttgart

Padeletti G, Fermo P (2010) A scientific approach to the attribution problem of renaissance ceramic productions based on chemical and mineralogical markers. Appl Phys A Mater Sci Process 100:771-784

Peserico A (1994) Monte Sirai 1. La ceramica fenicia: le forme aperte. Riv Stud Fenici XXII:117-144

Peserico A (1998) La ceramica fenicia da mensa: la produzione di Cartagine e delle altre regioni fenicie d'Occidente (VIII-VI sec. a.C.). In: Acquaro E, Fabbri B (eds) Produzione e circolazione della ceramica fenicia e punica nel Mediterraneo: il contributo delle analisi archeometriche. Atti della $2^{\mathrm{a}}$ Giornata di Archeometria della Ceramica (Ravenna, 14 maggio 1998). University Press Bologna, Imola, pp. 27-42

Peserico A (2000) Importazioni cartaginesi in Spagna, Sardegna e a Pithecusa. Uno studio archeologico e archeometrico. In: Bartoloni P, Campanella L (eds) La ceramica fenicia di Sardegna. Dati problematiche e confronti. Atti del primo Congresso Internazionale Sulcitano (Sant'Antioco, 19-21 Settembre 1997). Collezione di Studi Fenici, vol 40. Consiglio Nazionale delle Ricerche, Roma, pp. 269-275

Peserico A (2002) Die offenen Formen Red Slip Ware aus Karthago. Untersuchungen zur phönizischen Keramik im westlichen Mittelmeerraum. Hamburger Werkstattreihe zur Archäologie, 5. LIT, Münster

Ramon Torres J (1995) Las ánforas fenicio-púnicas del Mediterráneo central y occidental. Instrumenta, 2. Universitat de Barcelona, Barcelona

Trindade MJ, Dias MI, Coroado J, Rocha F (2009) Mineralogical transformations of calcareous rich clays with firing: a comparative study between calcite and dolomite rich clays from Algarve, Portugal. Appl Clay Sci 42:345-355 